\title{
REVIEW
}

\section{Understanding individual and population-level effects of plastic pollution on marine megafauna}

\author{
Jesse F. Senko ${ }^{1, *}{ }^{,}$Sarah E. Nelms ${ }^{2,3}$, Janie L. Reavis ${ }^{4}$, Blair Witherington ${ }^{5}$, \\ Brendan J. Godley ${ }^{2}$, Bryan P. Wallace ${ }^{6,7}$ \\ ${ }^{1}$ School for the Future of Innovation in Society, Arizona State University, Tempe, AZ 85287, USA \\ ${ }^{2}$ Marine Turtle Research Group, Centre for Ecology and Conservation, University of Exeter, Cornwall TR10 9EZ, UK \\ ${ }^{3}$ Plymouth Marine Laboratory, Prospect Place, Plymouth PL1 3DH, UK \\ ${ }^{4}$ School of Life Sciences, Arizona State University, Tempe, AZ 85287, USA \\ ${ }^{5}$ Inwater Research Group, Jensen Beach, FL 34957, USA \\ ${ }^{6}$ Ecolibrium Inc., Boulder, CO 80303, USA \\ ${ }^{7}$ Nicholas School of the Environment, Duke University Marine Lab, Beaufort, NC 28516, USA
}

\begin{abstract}
Plastic pollution is increasing rapidly throughout the world's oceans and is considered a major threat to marine wildlife and ecosystems. Although known to cause lethal or sub-lethal effects to vulnerable marine megafauna, population-level impacts of plastic pollution have not been thoroughly investigated. Here, we compiled and evaluated information from peer-reviewed studies that reported deleterious individual-level effects of plastic pollution on air-breathing marine megafauna (i.e. seabirds, marine mammals, and sea turtles) worldwide, highlighting those that assessed potential population-level effects. Lethal and sub-lethal individual-level effects included drowning, starvation, gastrointestinal tract damage, malnutrition, physical injury, reduced mobility, and physiological stress, resulting in reduced energy acquisition and assimilation, compromised health, reproductive impairment, and mortality. We found 47 studies published between 1969 and 2020 that considered population-level effects of plastic entanglement $(n=26)$, ingestion $(n=19)$, or both $(n=2)$. Of these, 7 inferred population-level effects $(n=6$, entanglement; $n=1$, ingestion), whereas 19 lacked evidence for effects $(n=12$, entanglement; $n=6$, ingestion; $n=1$, both). However, no study in the past $50 \mathrm{yr}$ reported direct evidence of population-level effects. Despite increased interest in and awareness of the presence of plastic pollution throughout the world's oceans, the extent and magnitude of demographic impacts on marine megafauna remains largely unassessed and therefore unknown, in contrast to well-documented effects on individuals. Addressing this major assessment gap will allow researchers and managers to compare relative effects of multiple threats -including plastic pollution-on marine megafauna populations, thus providing appropriate context for strategic conservation priority-setting.
\end{abstract}

KEY WORDS: Marine plastic - Marine debris · Population dynamics - Ingestion - Entanglement · Abandoned gear $\cdot$ Lost gear $\cdot$ Discarded gear $\cdot$ Ghost fishing $\cdot$ Marine mammal $\cdot$ Sea turtle $\cdot$ Seabird

\section{INTRODUCTION}

Plastic pollution is ubiquitous throughout the world's oceans and can originate from both land- and marinebased sources, such as public littering, sewage and drainage outflows, fisheries, and shipping (Barnes et

${ }^{*}$ Corresponding author: jesse.senko@asu.edu al. 2009, Ryan et al. 2009, Cózar et al. 2014, Nelms et al. 2017). Marine plastic pollution is increasing globally and accounts for up to $80 \%$ of anthropogenic waste accumulated on shorelines and in oceans (Barnes et al. 2009. Nelms et al. 2017). Today, over 5 trillion pieces of plastic, collectively weighing over

(1) The authors 2020. Open Access under Creative Commons by Attribution Licence. Use, distribution and reproduction are unrestricted. Authors and original publication must be credited. 
250000 tons, are estimated to be floating in the world's oceans (Eriksen et al. 2014).

Plastic persists in marine environments due to its chemically engineered durability, although it degrades, both physically and chemically, over time (Barnes et al. 2009, Cózar et al. 2014). Due to this persistence and increasing influx into the oceans, plastic is accumulating in a wide range of marine habitats, including shorelines, the seafloor in shallow waters as well as deep basins, and in all major ocean gyres (Barnes et al. 2009, Lebreton et al. 2012, Eriksen et al. 2014, Pham et al. 2014, Woodall et al. 2014). Due to its omnipresence, plastic pollution poses a risk to marine wildlife through ingestion, entanglement, and habitat degradation (Vegter et al. 2014).

To date, over 900 marine species have been observed interacting with plastic pollution (Vegter et al. 2014, Gall \& Thompson 2015, Provencher et al. 2017, Kühn \& van Franeker 2020). Air-breathing marine megafauna (i.e. seabirds, marine mammals, and sea turtles) are the taxa most commonly reported to incur effects (Kühn \& van Franeker 2020), although this may be biased given that observations of effects may be most apparent for these organisms and a large number of records come from dead individuals. Plastic pollution can cause lethal individual-level effects to marine megafauna from entanglement or ingestion, but can also lead to sub-lethal individual-level effects that may influence resource acquisition, health, and reproductive output (Nelms et al. 2015, Fig. 1). Ingestion frequency has been increasing globally in seabirds and sea turtles for decades (Robards et al. 1995, Ryan et al. 2009, Teuten et al. 2009, Schuyler et al. 2014a). Estimates suggest that $99 \%$ of all seabird species and $95 \%$ of the individuals within these species may have plastic in their digestive tracts by 2050 (Wilcox et al. 2015b). More than half (52\%) of the world's sea turtles are thought to have already ingested plastic material (Schuyler et al. 2016), with a predominance of microplastics (plastic particles $<5 \mathrm{~mm}_{\text {; }}$ Duncan et al. 2019a).

The global and pervasive nature of plastic pollution has gained substantial international attention and interest recently, both in the peer-reviewed literature and in popular media. This has included a growing number of studies documenting marine megafauna interactions with plastic pollution over the last half century (Vegter et al. 2014, Gall \& Thompson 2015, Provencher et al. 2017, Kühn \& van Franeker 2020), as well as visual imagery of dead or suffering animals (e.g. plastic-loaded seabird carcasses or entangled marine mammals) and their polluted habitats (e.g. oceanic 'garbage patches' or remote plastic-laden islands such as Midway Atoll). However, the effects of plastic pollution on marine megafauna populations relative to impacts of other threats have not been thoroughly investigated.

In this review, we compiled and evaluated available information from published studies that reported negative individual-level effects of plastic pollution on seabirds, marine mammals, and sea turtles worldwide, with a particular interest in highlighting studies that assessed potential populationlevel effects on these taxa. We conclude by discussing current knowledge gaps, recommendations for improving assessments of effects, and next phases for research and mitigation that could benefit marine megafauna.

\section{METHODS}

We conducted an extensive literature review to assess available information regarding populationlevel impacts of plastic pollution on air-breathing marine megafauna (i.e. seabirds, marine mammals, and sea turtles). Seabirds included any of the 414 species and corresponding families described by Ryan (2018), sea turtles included all 7 species, while marine mammals included cetaceans, pinnipeds (i.e.

Fig. 1. (on next page) Representative individual-level effects of plastic pollution on air-breathing marine megafauna (i.e. seabirds, marine mammals, and sea turtles) and their habitats: (A) adult humpback whale Megaptera novaeangliae entangled in a conglomerate of ghost fishing gear and other plastic materials, including over 22 different line types, off of Maui, Hawaii (photo: Ed Lyman, NOAA/MMHSRP permit \#9321489); (B) ringed seal Phoca hispida with plastic strap wrapped around its body along the coast of Alaska (photo taken by Alaska Fish and Game under ADFG research permits 3581888 and 358-1787); (C) juvenile Kemp's ridley turtle Lepidochelys kempii that ingested the latex end of a toy balloon, from which the synthetic ribbon trailed from the turtle and was wrapped around its front flippers, 65 nautical miles west of Sarasota, Florida (photo: Blair Witherington); (D) great egret Ardea alba entangled in recreational fishing line wrapped around its neck and beak, which appeared to be inhibiting its feeding, on a Florida Atlantic beach (photo: Blair Witherington); (E) Laysan albatross chick with ingested plastic after its death at Midway Atoll National Wildlife Refuge (photo: John Klavitter, USFWS); (F) olive ridley turtles Lepidochelys olivacea entangled at the surface in a conglomerate of ghost fishing gear in the Maldives, where turtles frequently become entangled in a single conglomerate of derelict gear (photo: Dave Bretherton/Olive Ridley Project); and (G) surface convergence front 'weedlines' in the northern Gulf of Mexico, which provide important oceanic habitat for marine megafauna, with accumulated Sargassum algae and a typical plastic load (photo: Blair Witherington) 

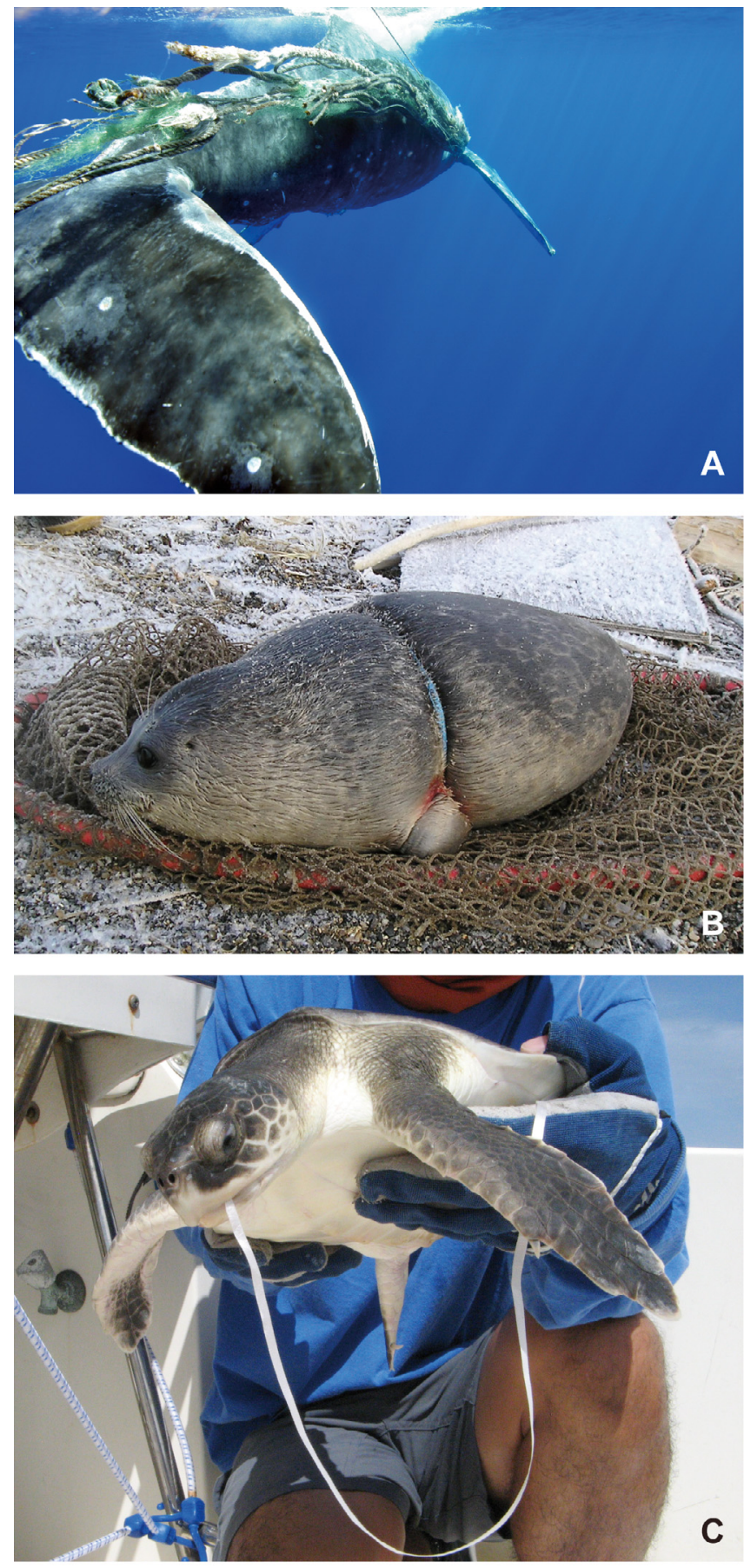

C

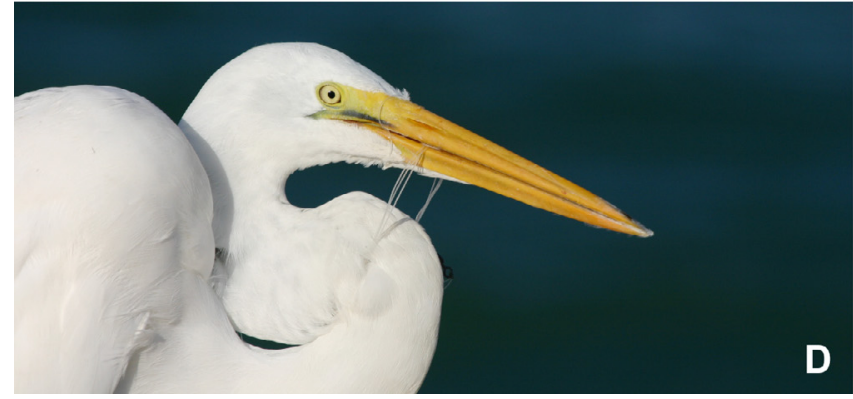

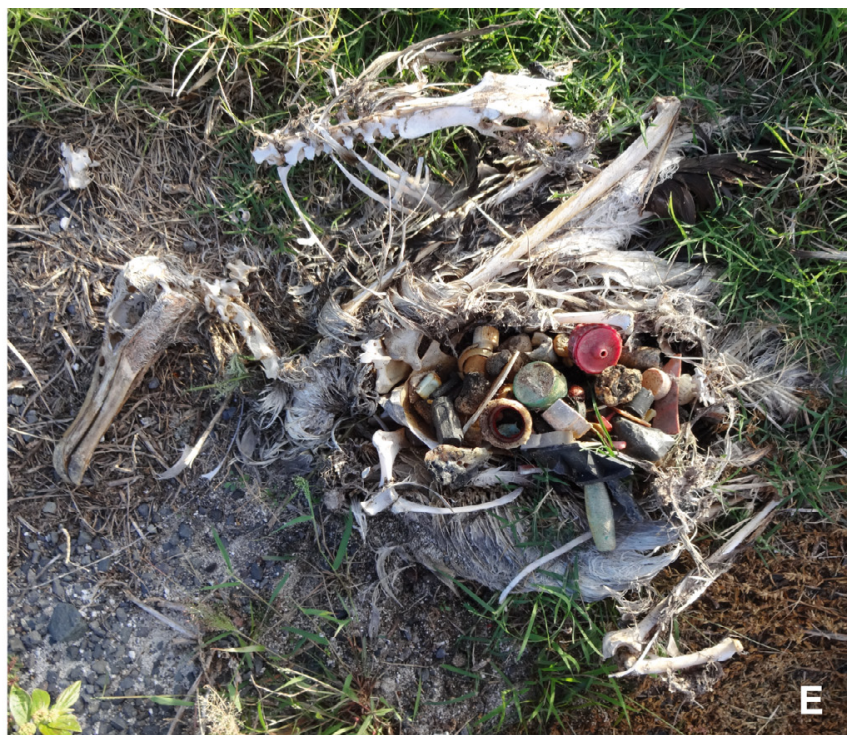
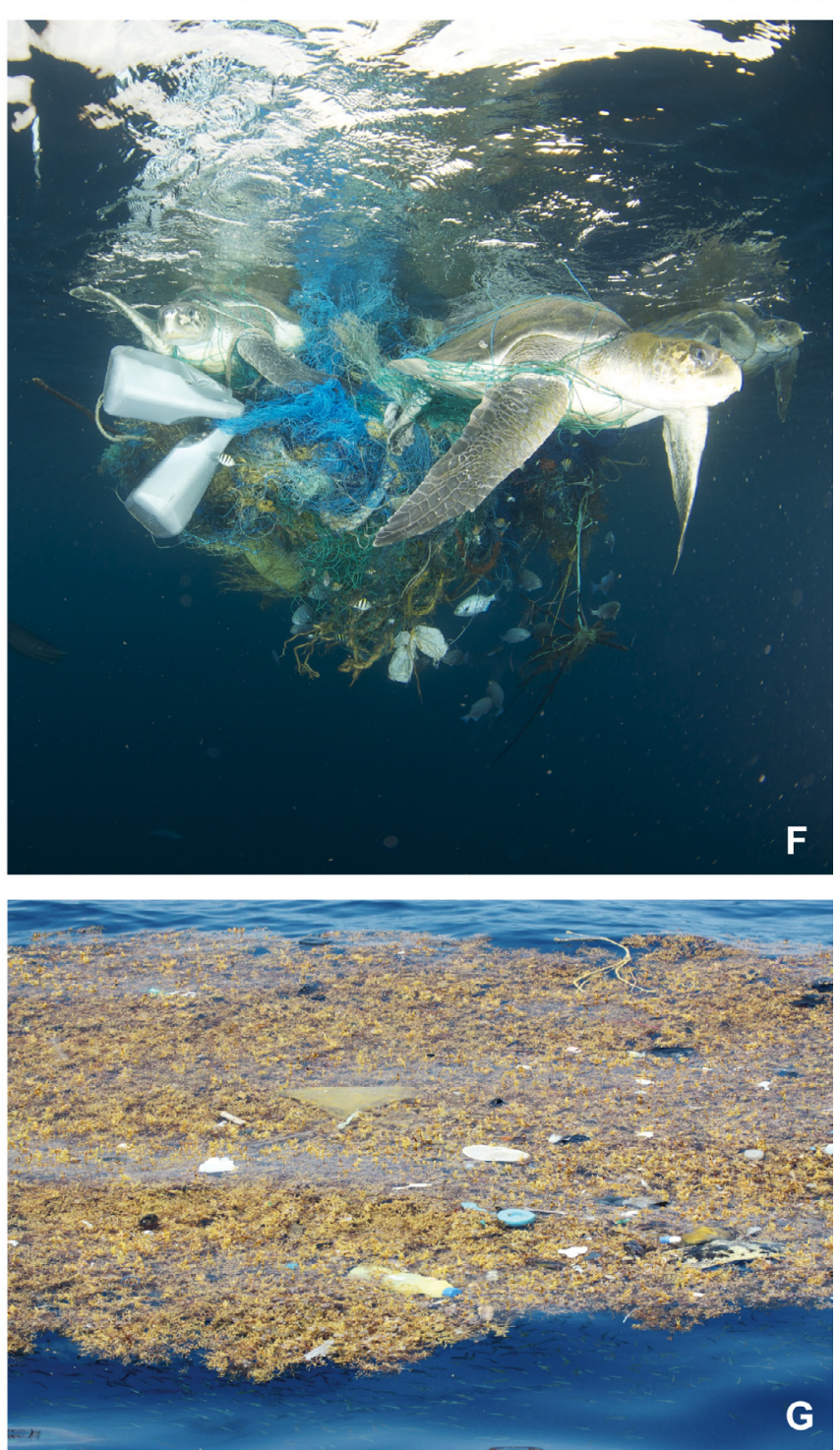
sea lions, seals, and walruses), sirenians (i.e. manatees and dugongs), sea otters, and polar bears. We searched ISI Web of Knowledge for articles published between 1969 and 2020 (last search was conducted on 7 February 2020) for the terms population, plastic, litter, debris, and ingest/entangle. Alongside each search term, we also incorporated the relevant taxon of interest, including marine mammal, cetacean, whale, dolphin, porpoise, seal, sea lion, walrus, dugong, manatee, sea cow, sea otter, turtle, seabird, and marine bird. Standard searches were augmented by the global database 'LITTERBASE' (https:// litterbase.awi.de/). Papers were further filtered for the words 'population' and 'demography', to determine whether the authors attempted to assess the effects of plastic pollution on marine megafauna populations. Although we did not include grey literature, we are confident that our literature review represents the current state of peer-reviewed knowledge regarding marine plastic interactions in these taxa.

Each published study was evaluated and filtered to remove cases where plastic pollution was not addressed independently from other threats or if the study was a review that lacked original data. We considered entanglement in derelict gear, but not entanglement in active fishing gear (i.e. bycatch). Data were collated based on the lowest taxonomic group, interaction type (i.e. entanglement and/or ingestion), individual effect (i.e. lethal or sub-lethal), location of interaction (i.e. ocean region), and number of individuals impacted (Dataset S1 in the Supplement at www.int-res.com/articles/suppl/n043p234 _supp.xlsx). Effects were classified as 'lethal' if an animal's cause of death was due to an interaction with plastic; all other effects were considered 'sub-lethal'.

We partitioned population-level assessments into 4 categories: (1) direct effects, i.e. the study provided direct evidence of population-level effects; (2) inferred effects, i.e. the study inferred population-level effects based on mortality rates or estimates, or pervasive sub-lethal individual-level effects that were likely to lead to decreased population size or growth, such as reduced reproductive output relative to the current population status (e.g. van der Hoop et al. 2017; see Table 1); (3) lacking evidence for effects, i.e. the study found no evidence for a populationlevel effect (e.g. Votier et al. 2011; see Table 1), and; (4) more data needed, i.e. the study concluded that there was insufficient evidence to determine if plastic pollution caused a population-level effect (e.g. Brandão et al. 2011, Dataset S1).

\section{OVERVIEW OF DOCUMENTED INDIVIDUAL-LEVEL EFFECTS OF PLASTIC POLLUTION ON MARINE MEGAFAUNA}

Understanding how plastic pollution affects individuals is a first step toward assessing populationlevel impacts (Browne et al. 2015). In this section we highlight the various pathways described in the literature by which marine megafauna interact with plastic pollution, and discuss their resulting individuallevel effects.

\subsection{Entanglement}

Marine megafauna can become entangled in plastic pollution including fibrous material, line, rope, packing bands, netting, and other packaging material. Animals may be attracted to plastic material in several ways, including (1) by curiosity or naivety (especially in immature animals); (2) to use as a resting platform, source of shelter, or nesting material; (3) to seek prey that is entangled in or attracted/ attached to the material (Matsuoka et al. 2005, Gregory 2009, Jensen et al. 2013, Duncan et al. 2017, Grant et al. 2018); or (4) by the odor of biofouled plastic, which may be mistaken for food (Pfaller et al. 2020). Compared to other plastic items, ghost or derelict fishing gear (i.e. gear that is abandoned, lost, or discarded) such as nets, pots, traps, lines, and buoys, is widely recognized as a major source of mortality in marine megafauna (Wilcox et al. 2016, Duncan et al. 2017).

\subsection{Physical injury and illness}

Entanglement in plastic pollution can lead to physical injuries that include lacerations, constriction (i.e. flesh clearly drawn in by impacting material, such as packing bands or monofilament line, which puts enough pressure on the animal's skin to impede blood or air flow; Allen et al. 2012), severe sclerosis, loss of limbs, and difficulty breathing if the airway becomes restricted (Snoddy et al. 2009, Vegter et al. 2014). The animal may starve, drown, or be unable to escape predators or hazards if the entangled material hampers movement (Gregory 2009, Barreiros \& Raykov 2014, Vegter et al. 2014, Nelms et al. 2015). Marine megafauna entangled in plastic ropes, lines, and floats may develop systemic infections and chronic debilitation from extensive tissue damage (Cassoff et al. 2011), and pinnipeds 
have been known to insert their heads through plastic packing bands, which can eventually lead to severed blood vessels (Fowler 1987). Entanglement of seabirds, both at sea and at terrestrial breeding sites, may reduce their flying and foraging efficiency (Derraik 2002, Voltier et al. 2011).

\subsection{Physiological stress}

Entanglement in plastic pollution can lead to severe physiological stress, inhibiting diving and resulting in increased hydrodynamic drag (Ceccarelli 2009, Macfayden et al. 2009, Gilardi et al. 2010, van der Hoop et al. 2014, Wilcox et al. 2015a). It is estimated that an entangled North Atlantic right whale Eubalaena glacialis incurred an increase in average locomotory power requirements of $70.5 \%$ when entangled in plastic rope (van der Hoop et al. 2014), while energy requirements for a California sea lion Zalophus californianus entangled in plastic netting increased 4 fold (Feldkamp 1985). In laboratory experiments, entangled fur seals reduced swimming time by $75 \%$, increased resting by $138 \%$, and increased their mean energy expenditure by $112 \%$ (Feldkamp et al. 1989). Several studies have shown that sea turtles entangled in active fishing gear for as little as 30 min-an experience that induces similar physiological responses to entanglement in derelict gear or other large plastic items-require additional time to rest and recover at the surface to replenish on-board oxygen stores consumed while involuntarily submerged (Gregory et al. 1996, Hoopes et al. 2000, Stabenau \& Vietti 2003, Harms et al. 2003, Snoddy \& Southwood Williard 2009, Snoddy et al. 2009). Upon release from entanglement (and submergence), Kemp's ridley Lepidochelys kempii and green turtles Chelonia mydas spent extended periods of time recovering at the surface, potentially increasing their vulnerability to predation and anthropogenic threats, such as vessel strikes (Snoddy et al. 2009, Snoddy \& Williard 2010). Despite an apparent lack of similar studies for seabirds, these animals are also likely to experience some form of physiological stress from submersion due to entanglement.

\subsection{Reduced mobility}

Plastic pollution may impede, obstruct, or entrap marine megafauna that rely on terrestrial environ- ments for resting or reproduction (e.g. seabirds, pinnipeds, and sea turtles). Plastic material has been known to affect adult and nestling seabirds, entangling their legs, feet, bill, and wings (Tasker et al. 2000, Votier et al. 2011, Bond et al. 2012). Synthetic materials present on sea turtle nesting rookeries can block nesting attempts or impede hatchlings. Extensive derelict fishing gear and other beach-cast plastic is believed to prevent nesting by sea turtles, while plastic objects have been observed impeding hatchling sea turtles from reaching the sea, potentially making them more susceptible to predation and decreased energy reserves required for the frenzy swim upon entering the water (Triessnig et al. 2012).

\subsection{Ingestion}

It is believed that marine megafauna ingest plastic for a number of reasons, including (1) mistaking the visual characteristics of the item for food (Gregory 2009, Schuyler et al. 2012, 2014b, Hoarau et al. 2014, Duncan et al. 2019b); (2) mistaking the odor of biofouled plastic as food (Pfaller et al. 2020); (3) accidentally, through non-selective feeding strategies such as filter feeding (Besseling et al. 2015) or if otherwise mixed with natural food items (Di Beneditto \& Awabdi 2014); (4) if the item is attached to or covered with natural prey (Frick et al. 2009); or (5) via trophic transfer from contaminated prey (Nelms et al. 2018).

\subsection{Gastrointestinal tract damage}

Ingested plastic objects may damage the gastrointestinal tract (GIT) of marine megafauna, causing ulcerations, perforations, lesions, or obstructions (Derraik 2002, Jacobsen et al. 2010, Brandão et al. 2011, Awabdi et al. 2013, Di Bello et al. 2013, Di Beneditto \& Awabdi 2014, Nelms et al. 2015). Gastrointestinal ulcerations or perforations and laceration of the larynx from ingesting plastic have been documented in seabirds, marine mammals, and sea turtles, and can result in chronic infection, peritonitis, gastrointestinal motility issues, septicemia, and mortality (Day et al. 1985, McCauley \& Bjorndal 1999, Levy et al. 2009, Guebert-Bartholo et al. 2011). Impaction or blockage of the GIT caused by plastic ingestion can inhibit digestion and cause pain, bloating, necrosis, hardened fecal matter, mechanical abrasion or blockage of absorptive surfaces in the 
digestive tract, and blockage of the cloaca which can prevent egg laying (Mader 2006, Guebert-Bartholo et al. 2011, Awabdi et al. 2013, Di Beneditto \& Awabdi 2014). Seabirds that ingest high levels of plastic may exhibit slower growth rates and earlier mortality (Pierce et al. 2004), while gut compactions and minor ulcerations caused by plastic ingestion in seabirds may result in reduced disease resistance and post-fledging survival (Fry et al. 1987).

\subsection{Dietary dilution}

Dietary dilution can occur when ingestion of plastic limits nutrient or water absorption. The presence of inorganic and space-occupying, non-food material within the GIT can cause a false sense of satiation, leading to a reduced desire to feed (McCauley \& Bjorndal 1999). Nutrient dilution is known to affect both juvenile and adult animals (Day et al. 1985, Sievert \& Sileo 1993, Bjorndal et al. 1994, McCauley \& Bjorndal 1999). Although sub-lethal, dietary dilution may lead to malnutrition, reduced energy, and eventual mortality. Loggerhead turtle hatchlings fed a $50 \%$ diluted diet with inert matter displayed significantly lower energy and nitrogen intake than hatchlings fed a $10 \%$ diluted diet, indicating that dietary dilution may decrease energy assimilation and allocation to somatic growth, which could reduce energy reserves and survivorship (McCauley \& Bjorndal 1999). Similarly, dietary dilution may dehydrate seabird chicks with already reduced fat reserves (Auman et al. 1997). Growth rates for Laysan albatross Phoebastria immutabilis that had ingested high volumes of plastic were significantly lower than for chicks that had ingested low volumes of plastic (Sievert \& Sileo 1993). Decreased body condition (reduced fledging weight), which can result from dietary dilution, has been found to decrease survival of juvenile seabirds (Braasch et al. 2009, Morrison et al. 2009).

\subsection{Exposure to contaminants associated with plastic pollution}

Plastic can adsorb and concentrate chemical contaminants, such as persistent organic pollutants (POPs), from the marine environment (Teuten et al. 2009). These toxic compounds can be harmful because they are inherently stable, persist for a long time, and can accumulate in adipose tissues following ingestion (D'Ilio et al. 2011). Many common poly- mers, such as polyethylene, have high sorptive capacities for toxicants due to their polymeric chain structure and enhanced surface area (Rochman et al. 2013). This capacity increases with degradation and a corresponding increase in surface area, which leads to the plastic becoming more hazardous the longer it remains in the marine environment (Andrady 2011). In addition to the adsorption of existing marine contaminants to their surfaces, plastic often contains toxic additives, monomers, and chemical byproducts as well as plasticizers, such as phthalates and bisphenol A (BPA), added during manufacturing (Teuten et al. 2009, Lithner et al. 2011).

POPs in marine megafauna tissues have been linked to plastic ingestion. Colabuono et al. (2010) found polychlorinated biphenyls (PCBs) and organochlorine pesticides in plastic pellets and fragments ingested by Procellariiforme seabirds in Southern Brazil, while Tanaka et al. (2013) reported that shorttailed shearwaters Puffinus tenuirostris found with plastic in their stomachs in the North Pacific had polybrominated diphenyl ethers in their abdominal adipose, which was also found in the same pieces of plastic. Likewise, lower chlorinated compounds were found to have transferred to short-tailed shearwaters as a result of ingesting contaminated plastic (Yamashita et al. 2011). At Midway Atoll, PCBs, polychlorinated dibenzo-p-dioxins, naphthalenes, and furans have been found in adult Laysan albatrosses (Jones et al. 1996), while PCBs were found to have transferred from contaminated plastic to streaked shearwater Calonectris leucomelas chicks in a feeding experiment (Teuten et al. 2009).

In addition to potential toxicity contamination via ingestion, prior research has found that transfer of chemicals that commonly occur in plastic (e.g. BPA) can occur through the skin (Geens et al. 2011, Zalko et al. 2011). Seabirds that nest on top of plastic material may absorb contaminants through their skin (Verlis et al. 2014), which could affect sexual development and potentially disrupt the endocrine system, resulting in reproductive difficulties and cancers (vom Saal et al. 2007, Talsness et al. 2009).

\subsection{Reduced mobility}

Plastic ingestion may affect the mobility of seabirds. Several seabird species rely on reducing wing-loading for flying and diving (Provencher et al. 2017). Thus, adding mass via ingestion may be detrimental to plastic-loaded birds (Provencher et al. 2017). 


\section{REVIEW OF STUDIES THAT CONSIDERED POPULATION-LEVEL EFFECTS OF PLASTIC POLLUTION ON MARINE MEGAFAUNA}

\subsection{Current state of knowledge on demographic impacts}

Population-level assessments of plastic pollution in marine megafauna have been reported infrequently over the past 50 yr (47 studies between 1969 and 2020; entanglement, $\mathrm{n}=26$; ingestion, $\mathrm{n}=19$; or both, $\mathrm{n}=2$; Fig. 2, Dataset S1), although reports are increasing (Fig. 3). Of these studies, 7 inferred populationlevel effects (entanglement, $\mathrm{n}=6$; ingestion, $\mathrm{n}=1$ ), whereas 19 studies lacked evidence for effects (entanglement, $\mathrm{n}=12$; ingestion, $\mathrm{n}=6$; both, $\mathrm{n}=1$; Fig. 2, Table 1, Dataset S1). The remaining studies reported insufficient evidence of population-level effects (Fig. 2, Dataset S1). We found no studies directly linking plastic hazard exposure to population (abundance) trends (Dataset S1).

\subsection{Summary of deleterious individual-level effects, global distribution, and species}

Of all published studies that considered population-level effects in marine megafauna, 6 reported lethal (entanglement, $\mathrm{n}=3$; ingestion, $\mathrm{n}=3$ ) and 29 reported sub-lethal (entanglement, $\mathrm{n}=17$; ingestion, $\mathrm{n}=11$; both, $\mathrm{n}=1$ ) effects (Dataset S1). Lethal and

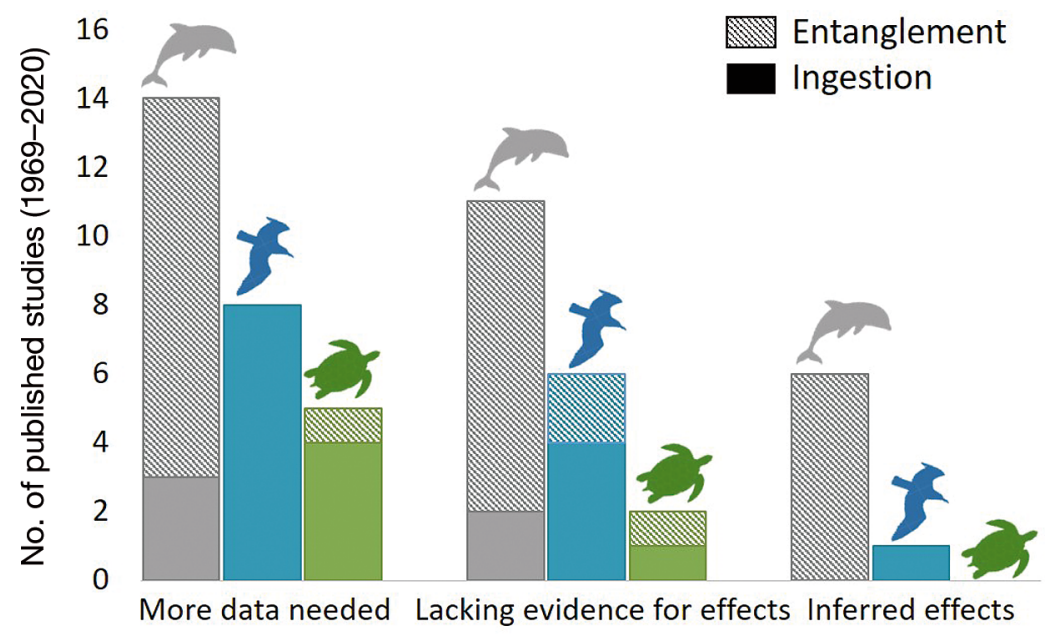

Fig. 2. Overview of findings from published, peer-reviewed studies that considered population-level effects of plastic pollution on air-breathing marine megafauna (i.e. marine mammals, seabirds, and sea turtles) worldwide between 1969 and 2020. See Dataset S1 for a complete list of species and studies as well as Table 1 for a summary of studies that inferred effects or were lacking evidence for effects sub-lethal effects included external lesions $(n=15)$, reduced mobility at sea or on land $(\mathrm{n}=9)$, GIT damage $(n=6)$, starvation $(n=4)$, malnutrition $(n=4)$, nutrient dilution $(\mathrm{n}=3)$, constriction $(\mathrm{n}=3)$, physiological stress $(n=3)$, and drowning $(n=2)$. Most research was conducted in the Atlantic $(45 \%)$ and Pacific (38\%) Ocean regions (Fig. 3, Dataset S1). Studies that assessed entanglement in marine mammals comprised $51 \%$ of all published studies (Fig. 3, Dataset S1). The species with the highest number of publications from entanglement and/or ingestion included harbour seals Phoca vitulina $(\mathrm{n}=6)$ and California sea lions $(\mathrm{n}=5)$, with 8 species represented in 3 or more studies (Fig. 4, Dataset S1)

\section{DISCUSSION}

\subsection{Assessments of population-level effects of plastic pollution on marine megafauna}

Understanding plastic pollution in a populationlevel context is crucial for prioritization of limited conservation resources to address competing threats (Avery-Gomm et al. 2018a). Our review underscores a dearth of empirical information to inform demographic assessments of impacts. We conclude that the extent and magnitude of population-level impacts on marine megafauna remain largely unassessed and thus unknown. We do not know if this is a reflection of the low detection power of current study designs or of the magnitude of effects. It is possible that plastic pollution does not present a major conservation threat to some marine megafauna populations at current levels. Conversely, as marine habitats and prey items become more polluted in the face of increasing environmental plastic worldwide (Barnes et al. 2009), its potential to cause population-level impacts may increase or become easier to detect with greater exposure and potency of effects, the latter of which assumes researchers would be conducting assessments of these impacts. Uncertainty over demographic effects from plastic pollution is in contrast to the well-documented effects on individuals, including slow and painful deaths, which raises serious concerns for animal welfare (Votier et al. 2011, Duncan et al. 2017). 


\section{Entanglement}
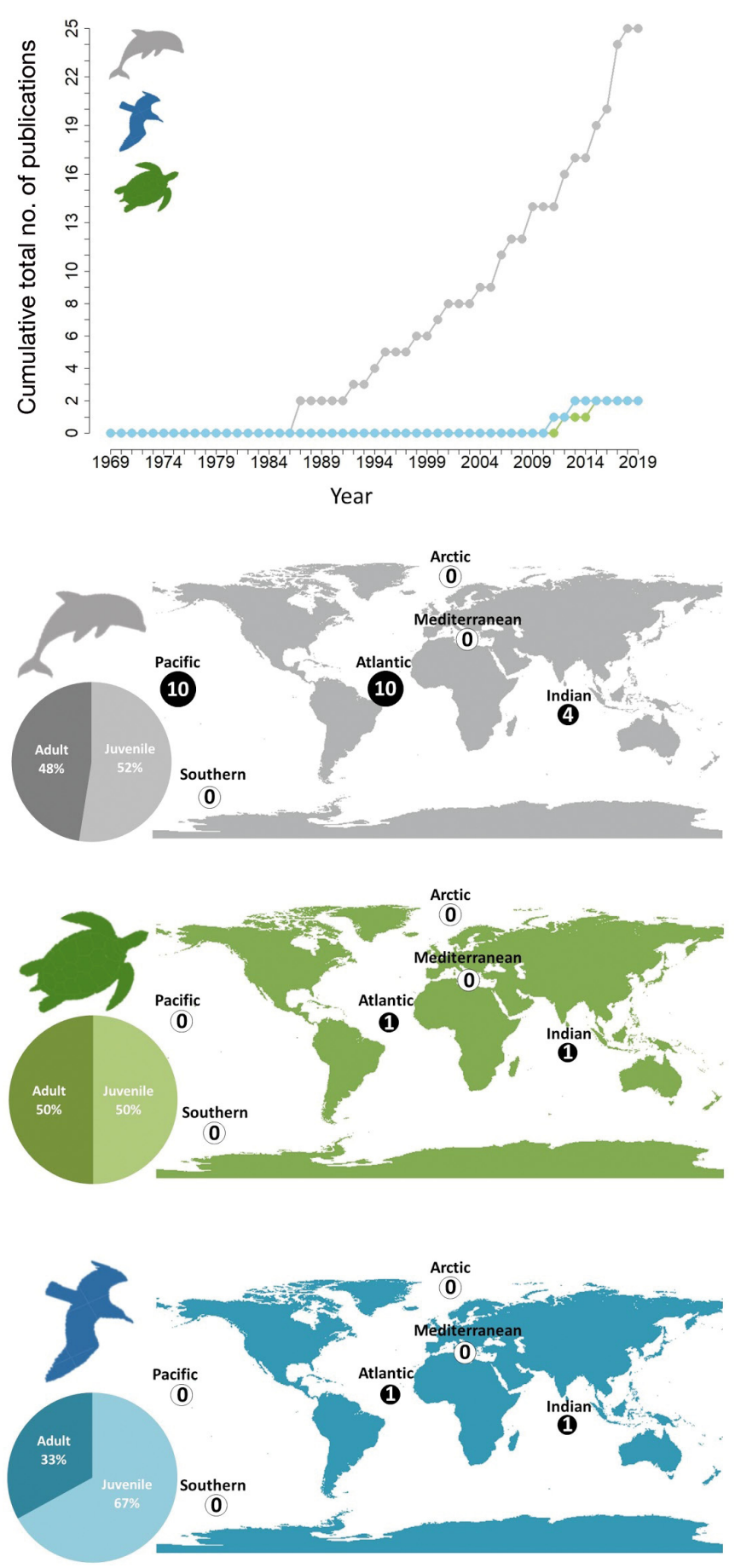

\section{Ingestion}
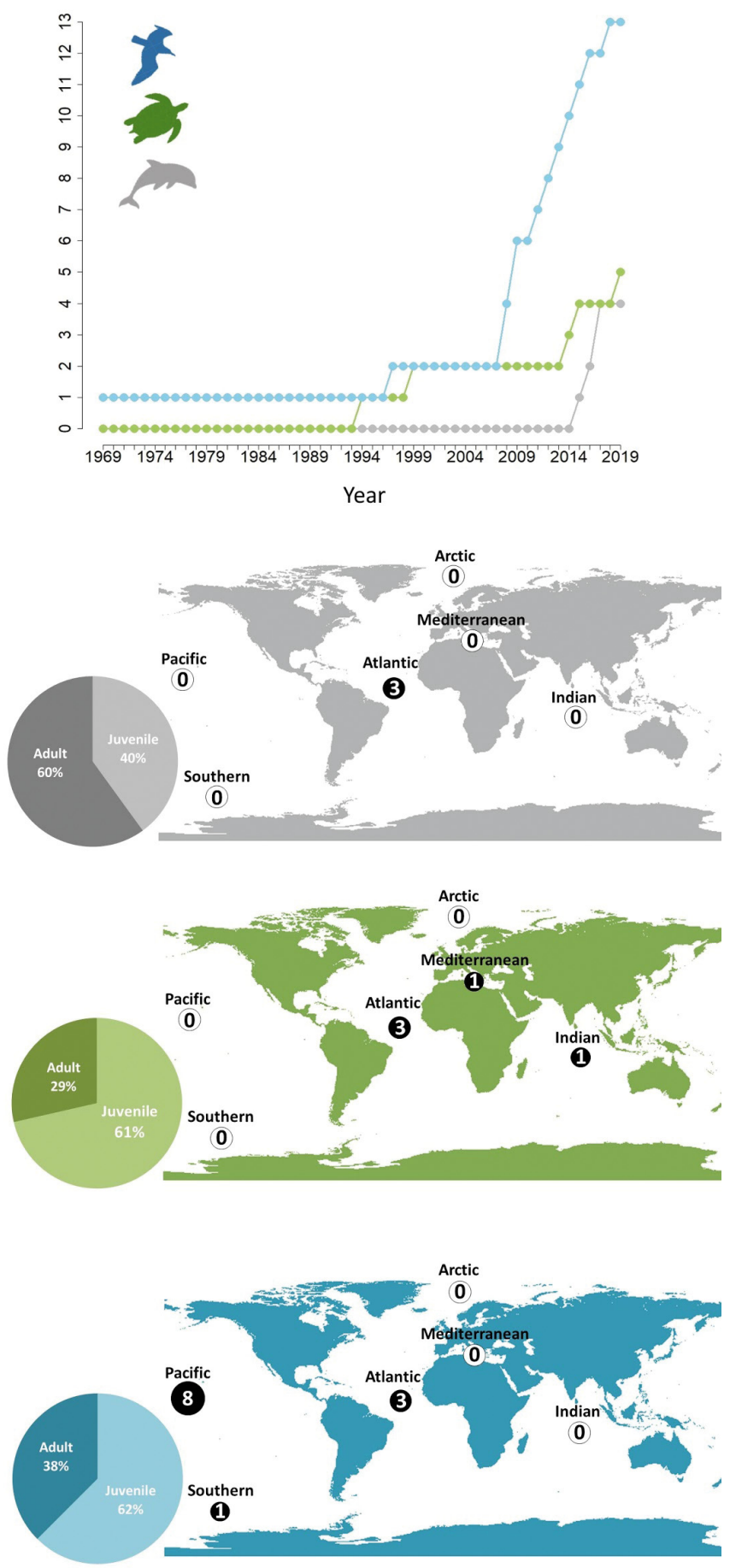

Fig. 3. Number of published, peer-reviewed studies that considered population-level effects of plastic pollution (entanglement and ingestion) on marine mammals (grey), sea turtles (green), and seabirds (blue) published between 1969 and 2020 (scatterplots), per age-class (pie charts) and ocean basin (maps). See Dataset S1 for a complete list of species and studies

Establishing population baselines and identifying trends for many marine megafauna populations is challenging due to their extensive migrations and large ranges. A crucial step will be to estimate the proportion of individuals in a population that are killed by plastic exposure in relation to their population size as well as the mortality they incur from other anthropogenic impacts (Browne et al. 2015). Popula- 


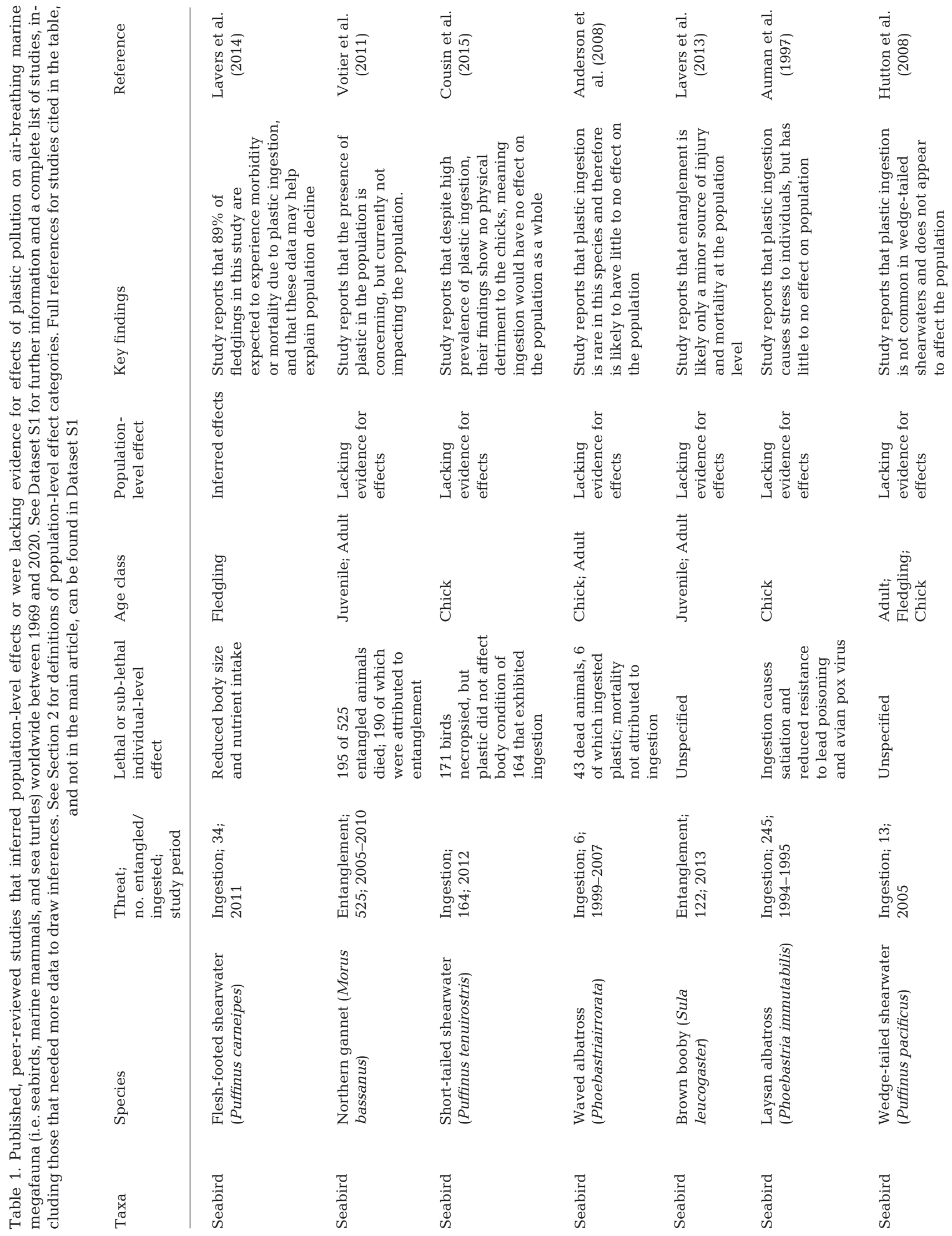




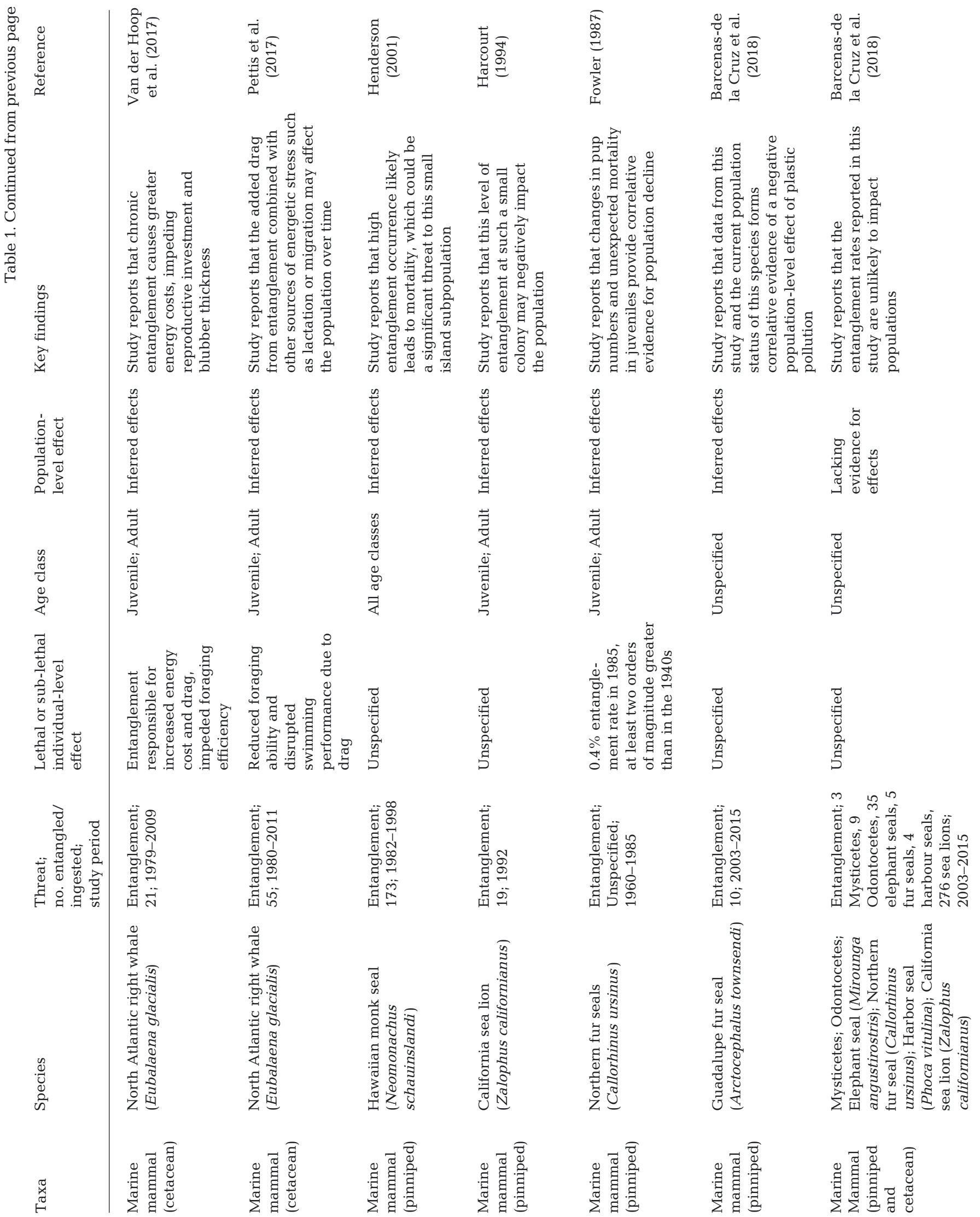


过

\begin{tabular}{|c|c|c|c|c|c|c|c|}
\hline & 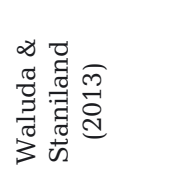 & 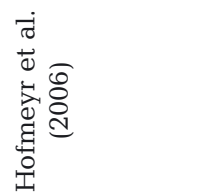 & 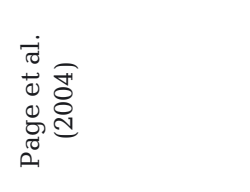 & 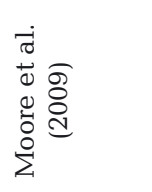 & 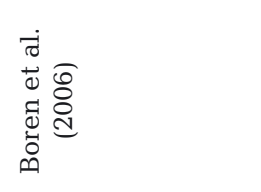 & 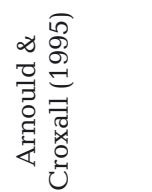 & 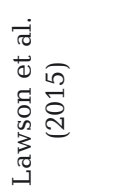 \\
\hline & 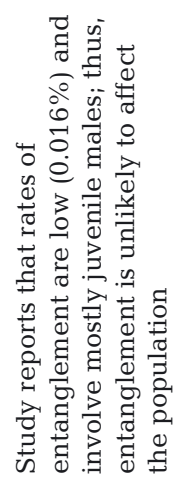 & 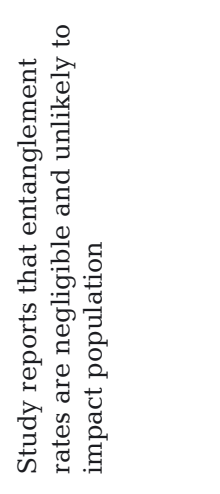 & 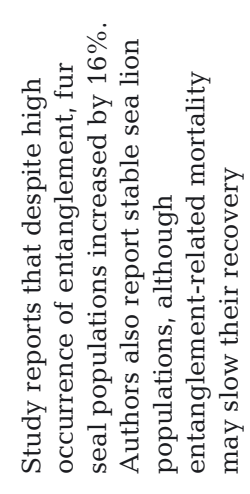 & 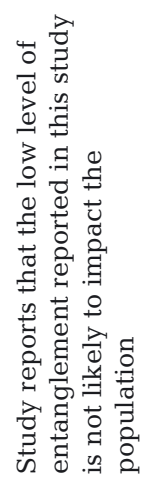 & 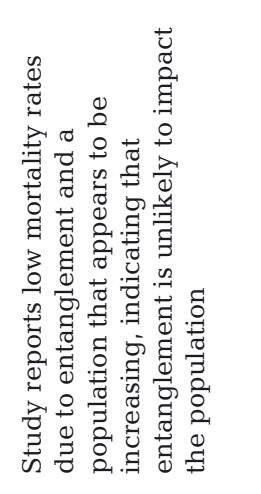 & 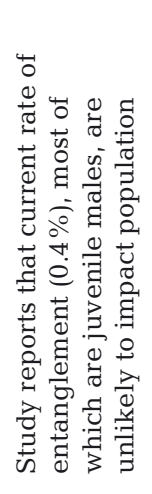 & 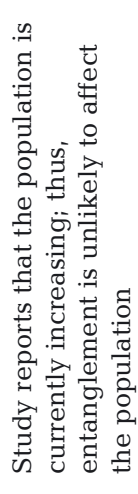 \\
\hline 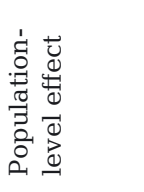 & 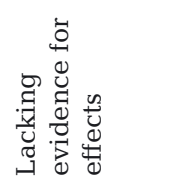 & 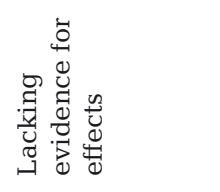 & 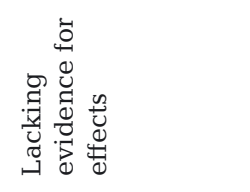 & 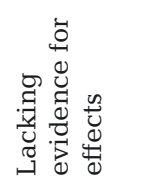 & 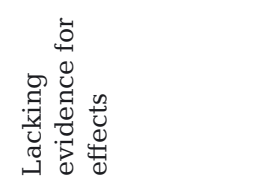 & 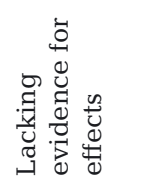 & 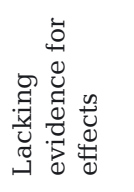 \\
\hline & $\begin{array}{l}0 \\
0 \\
0 \\
0 \\
0 \\
0 \\
0 \\
0 \\
\Xi \\
\approx\end{array}$ & $\begin{array}{l}0 \\
0 \\
w \\
0 \\
0 \\
0 \\
0 \\
0 \\
0 \\
\Xi\end{array}$ & 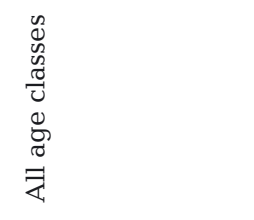 & 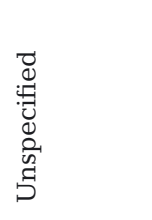 & 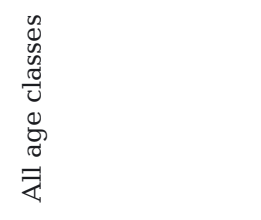 & 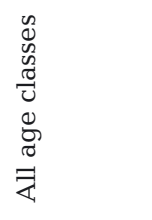 & 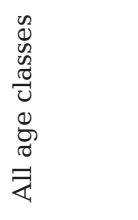 \\
\hline 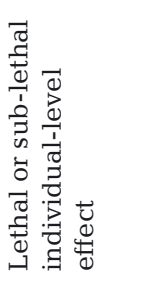 & 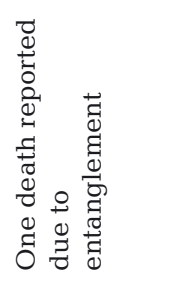 & 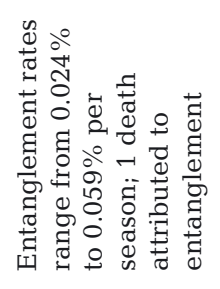 & 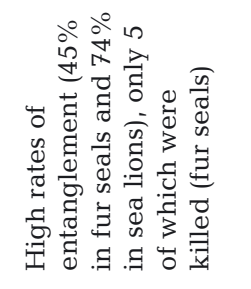 & 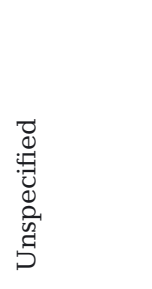 & 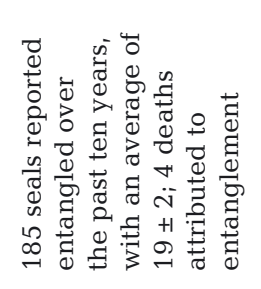 & 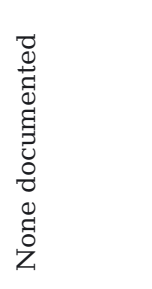 & 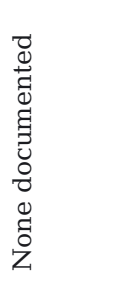 \\
\hline 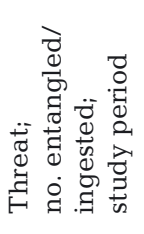 & 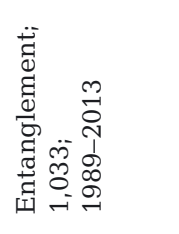 & 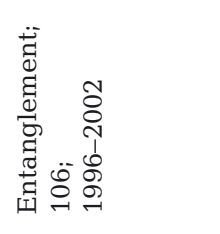 & 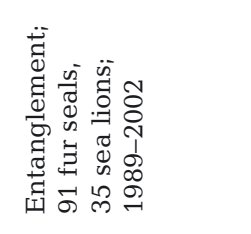 & 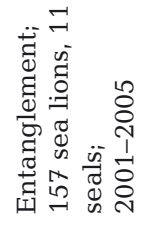 & 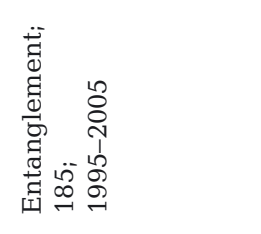 & 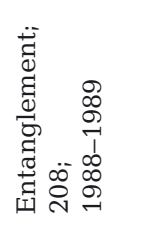 & 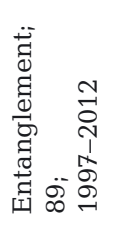 \\
\hline & 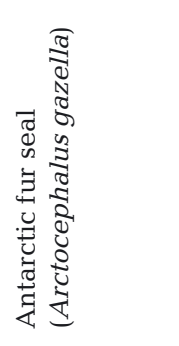 & 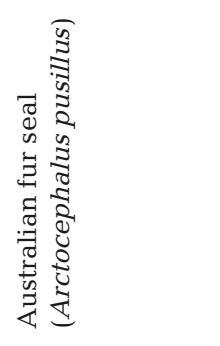 & 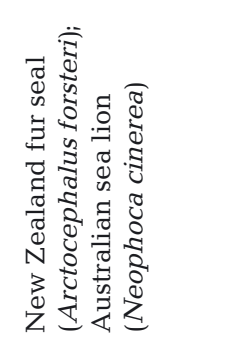 & 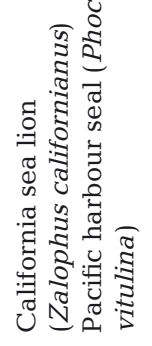 & 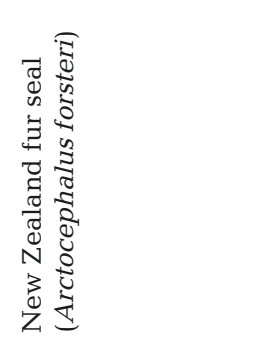 & 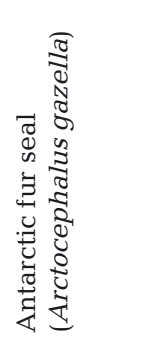 & 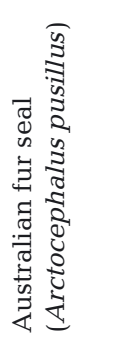 \\
\hline & 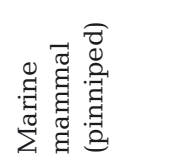 & 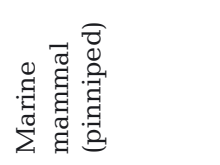 & 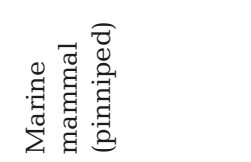 & 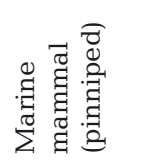 & 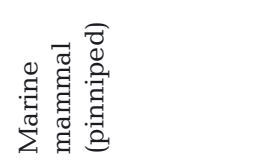 & 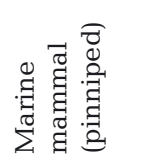 & 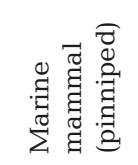 \\
\hline
\end{tabular}


8
0
0
0
0
0
0
0
0
0
0
0
0
0
0

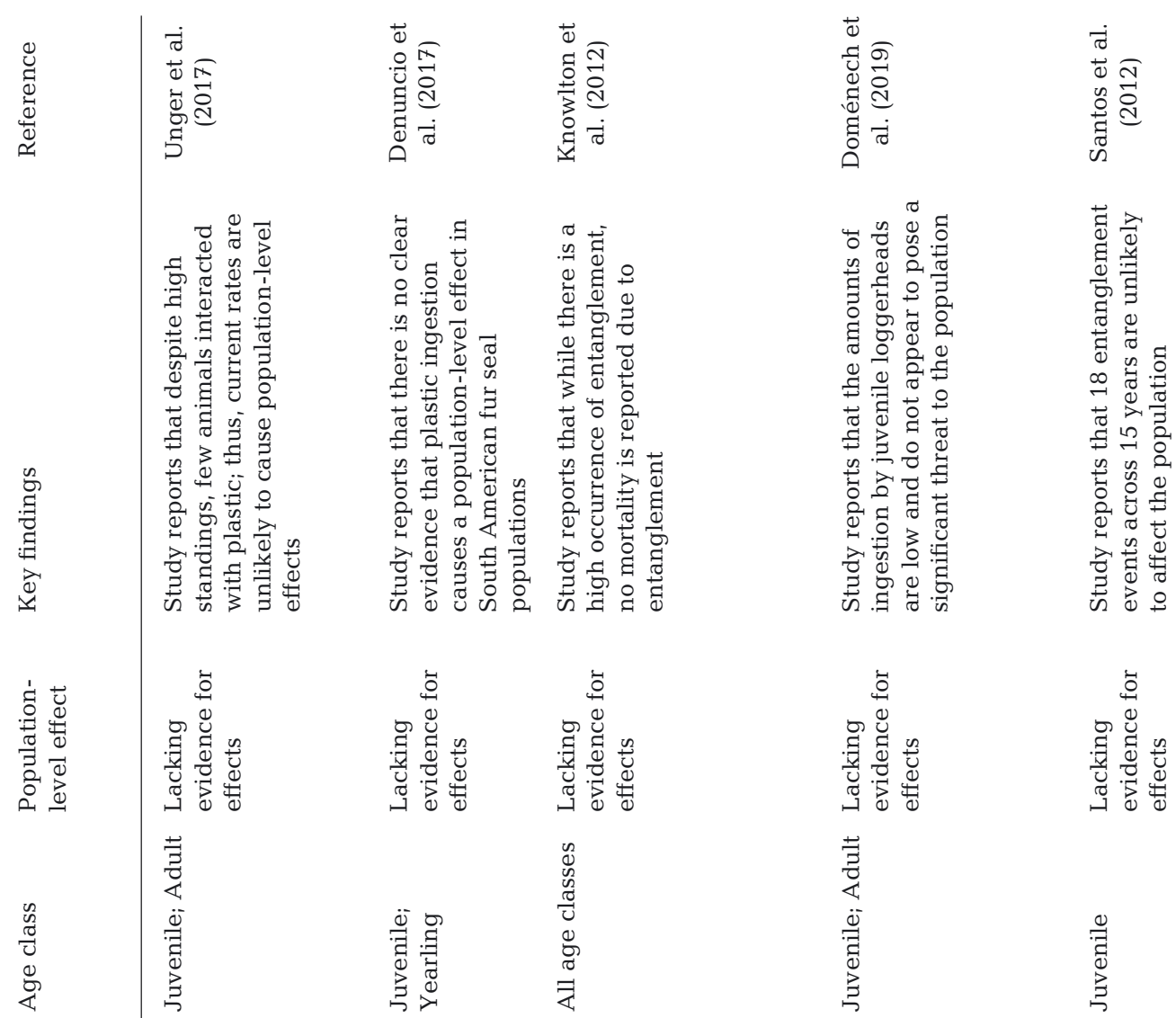

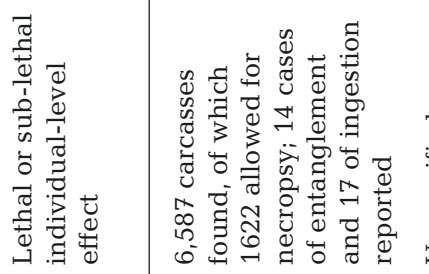

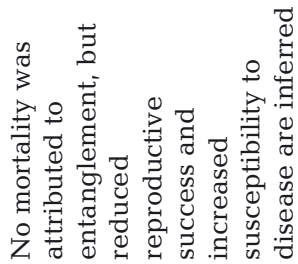

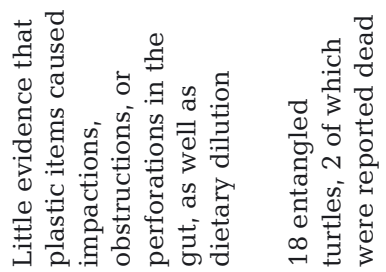

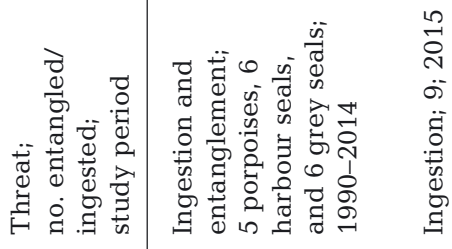

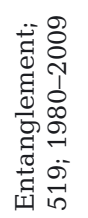

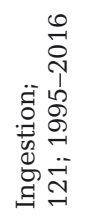

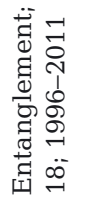

\begin{tabular}{|c|c|c|}
\hline & 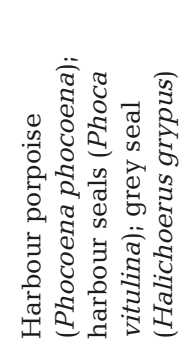 & 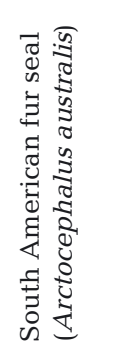 \\
\hline & 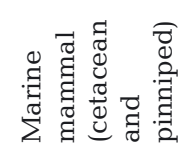 & 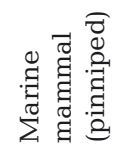 \\
\hline
\end{tabular}

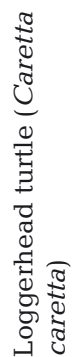

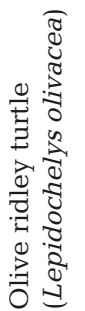

苛

节 


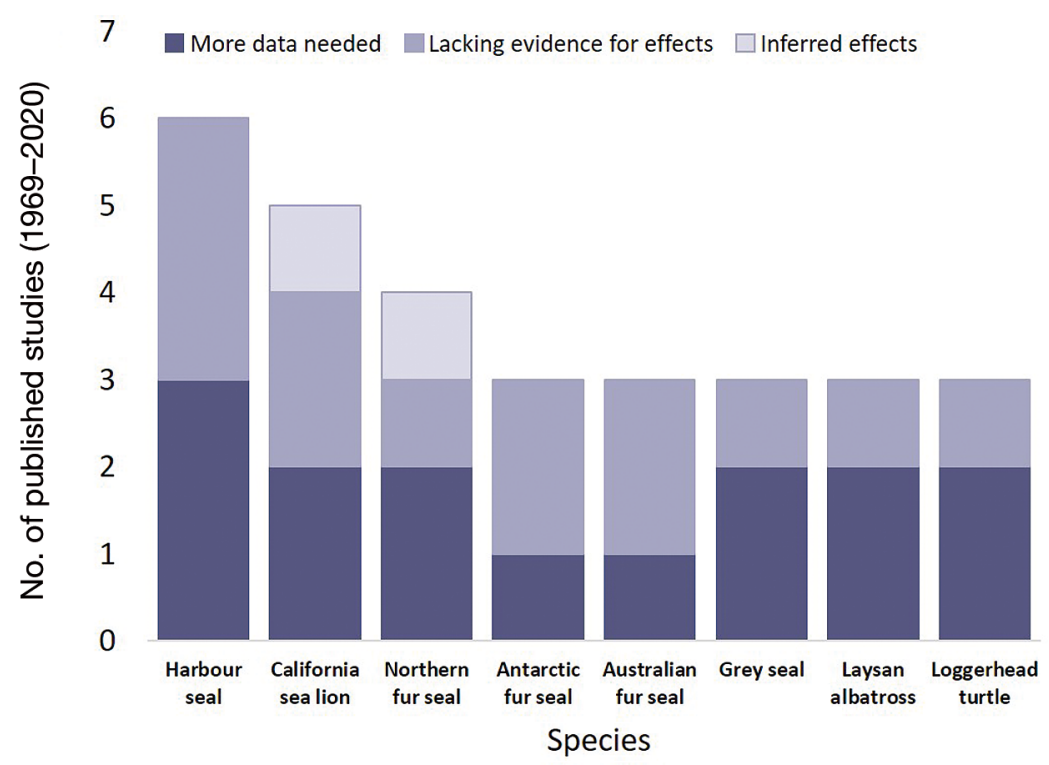

Fig. 4. Number of published, peer-reviewed studies that considered populationlevel effects of plastic pollution in species of air-breathing marine megafauna (i.e. seabirds, marine mammals, and sea turtles) that were reported in 3 or more studies worldwide between 1969 and 2020. See Dataset S1 for a complete list of species and studies

tion models can help elucidate potential impacts by incorporating a suite of metrics including relative contribution of a given lifestage (e.g. mature females), the size and growth rate of a population, mortality rates of different lifestages, and reproductive parameters (Bolten et al. 2011, Browne et al. 2015). Such approaches will permit side-by-side analyses of relative effects of multiple threats, including plastic, on marine megafauna population dynamics, rather than evaluating each threat in isolation. Outputs of these multi-threat assessments of population-level effects can provide managers and researchers with appropriate context in which to set conservation priorities.

\subsection{Patterns in plastic pollution effects on marine megafauna}

Although the list of species and catalog of effects on individual animals known to suffer detrimental effects from plastic pollution is incomplete, it is growing (Vegter et al. 2014, Gall \& Thompson 2015, Kühn \& van Franeker 2020). A more representative dataset of these effects, with spatial and temporal variation represented, will be necessary to better discern patterns and trends that could lead to population-level assessments. Where differential effects on species have been examined (Di Beneditto \& Awabdi 2014,
Kühn \& van Franeker 2020), patterns are apparent, but effects from habitats that differ by species generally remain unknown. One exception may be large-scale monitoring of northern fulmars Fulmarus glacialis as a means to understand the role of different habitats on plastic ingestion (e.g. Provencher et al. 2009, van Franeker et al. 2011, Avery-Gomm et al. 2012, 2018b, Kühn \& van Franeker 2012, Trevail et al. 2015, Terepocki et al. 2017). Some marine habitats bear an especially high plastic pollution load, such as remote islands within oceanic current fields (e.g. Midway Atoll). Spatial hotspots in plastic hazards have shown to be associated with dynamic oceanographic and geographic features such as frontal zones (Witherington 2002, Witherington et al. 2012, González Carman et al. 2014) as well as proximity to human population centers (Browne et al. 2010, González Carman et al. 2014). While understanding the impacts of marine plastic does not require a complete dataset on the spatio-temporal intersection of plastic and marine megafauna by species and population, it will require sufficient representative data to model these effects.

Some marine megafauna species or populations may be more tolerant of plastic interactions. Photographic studies of humpback whales Megaptera novaeangliae entangled in ghost (or active) gear in Alaska and the Gulf of Maine, USA, revealed that the majority of animals (52-78\%) had, in the past, been non-lethally entangled, suggesting that animals were eventually able to free themselves and survive the interaction (Neilson et al. 2009). In the Gulf of Maine, $48-65 \%$ of humpbacks were entangled between 1997 and 2002, of which 8-25\% were estimated to entangle annually (Robbins \& Mattila 2004). There are similar patterns of apparent tolerance with ingestion. Approximately $37 \%$ of 371 leatherback turtles Dermochelys coriacea autopsied from 1968-2007 had plastic in their GIT, yet of those, only $12(8.7 \%)$ appeared to die from it (Mrosovsky et al. 2009). Research also suggests that $75 \%$ of ingested plastic in petrels was no longer present within a month if no new plastic was consumed (van Franeker \& Law 2015). By contrast, documented entanglement rates for grey seals Halichoerus grypus from photo ID techniques in southwest England from 2004-2008 
revealed that $64 \%$ of entanglement events resulted in serious injuries, with significantly lower recapture rates of entangled seals, suggesting an elevated post-release mortality rate (Allen et al. 2012). Likewise, a surprisingly small amount of plastic (i.e. $0.5 \mathrm{~g}$ or one-tenth of a typical plastic bag) has been shown to block the digestive tract in juvenile green turtles (Santos et al. 2015), yet as much as $75 \mathrm{~g}$ (149 plastic items) can accumulate and remain in the gut of sea turtles without causing apparent damage (Hoarau et al. 2014). Lutz (1990) reported on plastic remaining in the gut of an apparently healthy captive loggerhead turtle for $4 \mathrm{mo}$. In the aforementioned cases, the volume, surface area, and rigidity of the plastic material was likely more important than its mass. More research is needed to understand plastic-interaction effects on demographic vital rates between species and populations.

In many marine megafauna species, effects of plastic pollution are likely to occur in marine habitats where detection of events is difficult or impossible (Gregory 2009). Thus, mortality caused by plastic pollution is likely to be under-reported. The comparatively large number of studies that assessed population-level effects in pinnipeds suggests that they may be easier to document given their close association with terrestrial habitats for reproduction, which would also apply to seabirds. Although sea turtles are also associated with terrestrial environments (i.e. nesting females), most species and populations tend to have large ranges and are not closely linked to these areas for the majority of their lives. Turtles and cetaceans that suffer serious injuries and subsequent mortality from plastic pollution may be more likely to die in open water, especially in the case of small juvenile sea turtles.

\subsection{Recommendations for improving assessments of plastic pollution effects on marine megafauna}

Plastic pollution can lead to lethal and sub-lethal effects, yet the latter are more difficult to identify and may be more prevalent and possibly even have broader population-level implications than lethal effects (Hoarau et al. 2014, Gall \& Thompson 2015). A handful of exemplar studies have focused on increased hydrodynamic drag, physiological stress, and nutrient dilution (e.g. McCauley \& Bjorndal 1999, Snoddy et al. 2009, Snoddy \& Williard 2010, van der Hoop et al. 2017; see Table 1). Linking sub-lethal effects with measurable fitness consequences (such as reduced energy acquisition and assimilation, in- creased energetic demands, and potentially harmful behavioral changes) from laboratory or field-based research will allow researchers to develop models that can assess long-term impacts in individuals and ultimately, populations. Field studies should combine tagging or telemetry techniques with physiological analyses to measure or infer post-plastic-interaction survival rates, growth rates, reproductive output, and health status for individual animals. For example, post-release mortality in juvenile sea turtles entangled in gillnets off the North Carolina coast was documented using both satellite telemetry and analysis of blood biochemistry (Snoddy \& Williard 2010). With advances in tagging technology, it will become logistically easier to assess the extent to which sub-lethal effects may become lethal or result in reproductive impairment. Moreover, information from tracking studies can be used to estimate potential transport of plastic mass entangling or ingested by seabirds and other marine megafauna (Provencher et al. 2017).

Acute, coarse-scale effects from plastic pollutants (e.g. entanglement, gut impaction) are more easily demonstrated than are chronic effects on a finer scale. Where investigated, microplastics appear to be ubiquitous in marine megafauna (Lusher et al. 2018, Duncan et al. 2019a, Nelms et al. 2019). However, gaps remain in our understanding of plastic ingestion, particularly microplastics and their potential to transfer and persist through marine food webs to marine megafauna or to be ingested directly by them (Nelms et al. 2018). Future research should assess the levels and effects of both microplastics and contaminants in animals of lower trophic levels, including the role that ingestion may play in biomagnifying adsorbed toxic chemicals common in plastic pollution up the food chain to marine megafauna.

Although many marine megafauna species are difficult to house in captivity, controlled studies can potentially shed light on post-entanglement and post-ingestion fate in marine megafauna. These studies will need to be evaluated on a case-by-case basis in terms of animal welfare, but surrogate species could potentially be used for endangered ones. These studies can control the amounts and types of plastic ingested, including chemical-laden plastic, as well as track weathering, dosage, and components of the introduced items. Researchers can concurrently track changes in feeding, weight, growth rates, and other behaviors to gain a better understanding of how marine megafauna might be affected, which can ultimately be used to infer possible population-level 
impacts where interaction rates are well documented or believed to be high.

Attributing marine megafauna mortality to plastic ingestion or entanglement is complex and challenging, even for trained veterinary pathologists. In many cases, cause of death may be recorded as a symptom of entanglement or ingestion, such as infection, which may mean plastic pollution mortalities are underrecorded. Conversely, an animal that died with plastic in its stomach may be assumed to have been killed by it, when it is possible that the animal was not feeding normally due to compromised health (Casale et al. 2016, Lynch 2018, Rodríguez et al. 2018, Nelms et al. 2019). Marine megafauna can face several confounding threats such as fisheries interactions, habitat degradation, noise pollution, and climate change, which may become interactive, additive, or negating. Controlled studies (see previous paragraph) may help determine the impacts of additive effects, such as ingesting contaminated plastic. Further research is needed to better understand how other threats interact with the risk posed by plastic pollution.

Methodologies used to assess effects of plastic risk exposure need to be carefully considered. Differences in plastic collection techniques from dead (e.g. causes of death for necropsied animals) or live (e.g. esophagus lavage or feces) animals can make it difficult to draw meaningful comparisons within and amongst studies (Casale et al. 2016, Lynch 2018, Rodríguez et al. 2018, Nelms et al. 2019). To avoid overestimating ingestion frequency and amounts among individuals, researchers are now beginning to call for studies to publish both positive and negative results to better understand the overall impacts of plastic pollution (Nelms et al. 2015, Lynch 2018). Most sea turtle and seabird plastic ingestion studies have used frequency of occurrence to assess ingestion; however, this metric does not depict the amount of material that was actually ingested by the animal, which limits its usefulness and can bias-sometimes substantially - results in terms of actual risk (Lynch 2018). Where possible, Lynch (2018) recommends that researchers measure plastic ingestion by debris mass per turtle mass $\left(\mathrm{g} \mathrm{kg}^{-1}\right)$ in order to better identify at-risk populations.

We recommend a strong emphasis on thorough veterinary examinations of live animals and necropsies of dead animals. The development of a global database of effects of plastic pollution from health assessments and necropsies would help provide information on the extent and frequency of plastic interactions with marine megafauna (Nelms et al. 2015).

\subsection{Next phases for plastic pollution research and mitigation}

Potential solutions to hazardous plastic in the environment are as complex as for any other pollutant, involving sociopolitical considerations for changing human behavior as well as engineering solutions to mitigate escape of plastic during transport, to improve efficiency of waste collection and disposal, and to develop alternative and more degradable materials (Gold et al. 2013, Provencher et al. 2020). Although these solutions are outside the scope of our review, we point to avenues of investigation that would inform solutions benefitting marine megafauna specifically.

A fundamental piece of the puzzle is understanding the origins of plastic pollution that pose a hazard to marine animals. Forensic investigations into errant plastics have revealed general source points and original usage categories (Woodall et al. 2015), but this work is at a scale dwarfed by the global scope of plastic pollution. Conversely, data on plastic waste mismanagement by country (Jambeck et al. 2015) provides information on a broad scale, but does not identify hazard origins relative to marine habitats. Modeling ocean surface currents has the potential to describe geographic origin of plastic pollution in drift patches (van Sebille et al. 2012), which can identify human population centers for outreach and technology transfer. Plastic pollution sources might also come from identifying original usage. Original use identification could be as direct as matching shapes, colors, and lettering of plastic in marine habitats to cataloged items, and as inferential as assuming use applications based on resin identification from spectroscopy (Zettler et al. 2013, Rocha-Santos \& Duarte 2015).

Comprehensive efforts to better understand and mitigate the effects of plastic pollution on marine species and ecosystems worldwide are urgently needed. Mitigation can be achieved in part by reducing the use of disposable and short-lived plastic items and more effective recycling programs (Hopewell et al. 2009). Reducing the exposure of marine megafauna to plastic will require lowering the plastic loading rate. Based on studies of the origin of plastic pollution cast on marine beaches (Pruter 1987, Derraik 2002) and at sea (Ryan et al. 2009), there are many sources. Identifying major origins of plastic pollution would guide public outreach efforts, enforcement, and export of trash management technology and methods. Re-designed or modified fishing gear, coupled with policy initiatives that include economic incen- 
tives or deterrents, should be developed as a means to reduce gear loss and discarding at sea (Wilcox et al. 2016).

Finally, we highlight and encourage the multidisciplinary nature of potential solutions to threats from marine plastic pollution. Ocean research is not likely to result in information helpful for reducing this threat without work coordinated between resource experts, oceanographers, sociologists, materials scientists, and specialists in achieving human behavior change.

Acknowledgements. We thank Wallace J. Nichols for the inspiration behind this paper, Patrick Fraher for designing Fig. 1, Jillian Hudgins, Ed Lyman, Kim Raum-Suryan, and John Klavitter for providing images, and Sydney Hitzig, Christa Burgess, Kinley Ragan, and Mattie Rodrigue for helping collate studies. This work was partially based on the $\mathrm{PhD}$ thesis of S.E.N. (funded by the Natural Environment Research Council [NE/L002434/1]) at Plymouth Marine Laboratory and the University of Exeter. Christopher Pincetich, Wallace J. Nichols, and 2 anonymous reviewers provided helpful comments and suggestions that improved the manuscript.

\section{LITERATURE CITED}

Allen R, Jarvis D, Sayer S, Mills C (2012) Entanglement of grey seals Halichoerus grypus at a haul out site in Cornwall, UK. Mar Pollut Bull 64:2815-2819

Andrady AL (2011) Microplastics in the marine environment. Mar Pollut Bull 62:1596-1605

Auman HJ, Ludwig JP, Giesy JP, Colborn T (1997) Plastic ingestion by Laysan albatross chicks on Sand Island Midway Atoll, in 1994 and 1995. In: Robinson G, Gales R (eds) Albatross biology and conservation. Surrey Beatty \& Sons, Chipping Norton, p 239-244

Avery-Gomm S, O'Hara PD, Kleine L, Bowes V, Wilson LK, Barry KL (2012) Northern fulmars as biological monitors of trends of plastic pollution in the Eastern North Pacific. Mar Pollut Bull 64:1776-1781

Avery-Gomm S, Borrelle SB, Provencher JF (2018a) Linking plastic ingestion research with marine wildlife conservation. Sci Total Environ 637-638:1492-1495

Avery-Gomm S, Provencher JF, Liboiron M, Poon FE, Smith PA (2018b) Plastic pollution in the Labrador Sea: an assessment using the seabird northern fulmar Fulmarus glacialis as a biological monitoring species. Mar Pollut Bull 127:817-822

Awabdi DR, Siciliano S, Di Beneditto APM (2013) Ingestão de resíduos sólidos por tartarugas-verdes juvenis, Chelonia mydas (L. 1758), na costa leste do estado do Rio de Janeiro, Brasil. Biotemas 26:197-200

* Barnes DKA, Galgani F, Thompson RC, Barlaz M (2009) Accumulation and fragmentation of plastic debris in global environments. Philos Trans R Soc B 364: 1985-1998

Barreiros JP, Raykov VS (2014) Lethal lesions and amputation caused by plastic debris and fishing gear on the loggerhead turtle Caretta caretta (Linnaeus, 1758). Three case reports from Terceira Island, Azores (NE Atlantic). Mar Pollut Bull 86:518-522
Besseling E, Foekema EM, Van Franeker JA, Leopold MF and others (2015) Microplastic in a macro filter feeder: humpback whale Megaptera novaeangliae. Mar Pollut Bull 95:248-252

Bjorndal KA, Bolten AB, Lagueux CJ (1994) Ingestion of marine debris by juvenile sea turtles in coastal Florida habitats. Mar Pollut Bull 28:154-158

Bolten AB, Crowder LB, Dodd MG, MacPherson SL and others (2011) Quantifying multiple threats to endangered species: an example from loggerhead sea turtles. Front Ecol Environ 9:295-301

* Bond AL, Montevecchi WA, Guse N, Regular PM, Garthe S, Rail JF (2012) Marine debris in the nests of a large colonial seabird is related to fishing effort. Mar Pollut Bull 64: 907-911

Braasch A, Schauroth C, Becker PH (2009) Post-fledging body mass as a determinant of subadult survival in common terns Sterna hirundo. J Ornithol 150:401-407

Brandão ML, Braga KM, Luque JL (2011) Marine debris ingestion by Magellanic penguins, Spheniscus magellanicus (Aves: Sphenisciformes), from the Brazilian coastal zone. Mar Pollut Bull 62:2246-2249

* Browne MA, Galloway TS, Thompson RC (2010) Spatial patterns of plastic debris along estuarine shorelines. Environ Sci Technol 44:3404-3409

* Browne MA, Underwood AJ, Chapman MG, Williams R, Thompson RC, van Franeker JA (2015) Linking effects of anthropogenic debris to ecological impacts. Proc R Soc B 282:20142929

Casale P, Freggi D, Paduano V, Oliverio M (2016) Biases and best approaches for assessing debris ingestion in sea turtles, with a case study in the Mediterranean. Mar Pollut Bull 110:238-249

Cassoff RM, Moore KM, McLellan WA, Barco SG, Rotstein DS, Moore MJ (2011) Lethal entanglement in baleen whales. Dis Aquat Org 96:175-185

Ceccarelli DM (2009) Impacts of plastic debris on Australian marine wildlife. Department of the Environment, Water, Heritage and the Arts, Canberra

Colabuono FI, Taniguchi S, Montone RC (2010) Polychlorinated biphenyls and organochlorine pesticides in plastic ingested by seabirds. Mar Pollut Bull 60:630-634

* Cózar A, Echevarría F, González-Gordillo JI, Irigoien X, Úbeda B, Hernández-León S (2014) Plastic debris in the open ocean. Proc Natl Acad Sci USA 111: 10239-10244

* D'Ilio S, Mattei D, Blasi MF, Alimonti A, Bogialli S (2011) The occurrence of chemical elements and POPs in loggerhead turtles (Caretta caretta): an overview. Mar Pollut Bull 62:1606-1615

Day RH, Wehle DHS, Coleman FC (1985) Ingestion of plastic pollutants by marine birds. In: Shomura RS, Yoshida HO (eds) Proceedings of the workshop on the fate and impact of marine debris, 27-29 November 1984, Honolulu, HI. NOAA Tech Memo NMFS-SWFC54:344-386

Derraik JGB (2002) The pollution of the marine environment by plastic debris. Mar Pollut Bull 44:842-852

* Di Bello A, Valastro C, Freggi D, Lai OR, Crescenzo G, Franchini D (2013) Surgical treatment of injuries caused by fishing gear in the intracoelomic digestive tract of sea turtles. Dis Aquat Org 106:93-102

* Di Beneditto APM, Awabdi DR (2014) How marine debris ingestion differs among megafauna species in a tropical coastal area. Mar Pollut Bull 88:86-90 
Duncan EM, Botterell ZLR, Broderick AC, Galloway TS and others (2017) A global review of marine turtle entanglement in anthropogenic debris: a baseline for further action. Endang Species Res 34:431-448

* Duncan EM, Broderick AC, Fuller WJ, Galloway TS and others (2019a) Microplastic ingestion ubiquitous in marine turtles. Glob Change Biol 25:744-752

Duncan EM, Arrowsmith JA, Bain CE, Bowdery H and others (2019b) Diet-related selectivity of macroplastic ingestion in green turtles (Chelonia mydas) in the Eastern Mediterranean. Sci Rep 9:11581

Eriksen M, Lebreton LCM, Carson HS, Thiel M and others (2014) Plastic pollution in the world's oceans: more than 5 trillion plastic pieces weighing over 250,000 tons afloat at sea. PLOS ONE 9:e111913

Feldkamp SD (1985) The effects of net entanglement on the drag and power output of a California sea lion, Zalophus californianus. Fish Bull 84:692-695

Feldkamp SD, Costa DP, Dekrey GK (1989) Energetic and behavioral effects of net entanglement on juvenile northern fur seals, Callorhinus ursinus. Fish Bull 87:85-94

* Fowler CW (1987) Marine debris and northern fur seals: a case study. Mar Pollut Bull 18:326-335

Frick MG, Williams KL, Bolten AB, Bjorndal KA, Martins HR (2009) Foraging ecology of oceanic-stage loggerhead turtles Caretta caretta. Endang Species Res 9:91-97

* Fry DM, Fefer SI, Sileo L (1987) Ingestion of plastic debris by Laysan albatrosses and wedge tailed shearwaters in the Hawaiian Islands. Mar Pollut Bull 18:339-343

Gall SC, Thompson RC (2015) The impact of debris on marine life. Mar Pollut Bull 92:170-179

*Geens T, Goeyens L, Covaci A (2011) Are potential sources for human exposure to bisphenol-A overlooked? Int J Hyg Environ Health 214:339-347

* Gilardi KVK, Carlson-Bremer D, June JA, Antonelis K, Broadhurst G, Cowan T (2010) Marine species mortality in derelict fishing nets in Puget Sound, WA and the cost/benefits of derelict net removal. Mar Pollut Bull 60: 376-382

Gold M, Mika K, Horowitz C, Herzog M (2013) Stemming the tide of plastic litter: a global action agenda. Pritzker Brief No. 5, UCLA School of Law and the Emmett Center on Climate Change and the Environment, Los Angeles, CA

González Carman V, Acha EM, Maxwell SM, Albareda D, Campagna C, Mianzan H (2014) Young green turtles, Chelonia mydas, exposed to plastic in a frontal area of the SW Atlantic. Mar Pollut Bull 78:56-62

Grant ML, Lavers JL, Stuckenbrock S, Sharp PB, Bond AL (2018) The use of anthropogenic marine debris as a nesting material by brown boobies (Sula leucogaster). Mar Pollut Bull 137:96-103

* Gregory MR (2009) Environmental implications of plastic debris in marine settings-entanglement, ingestion, smothering, hangers-on, hitch-hiking and alien invasions. Philos Trans R Soc B 364:2013-2025

* Gregory LF, Gross TS, Bolten AB, Bjorndal KA, Guillette LJ Jr (1996) Plasma corticosterone concentrations associated with acute captivity stress in wild loggerhead sea turtles (Caretta caretta). Gen Comp Endocrinol 104: 312-320

* Guebert-Bartholo FM, Barletta M, Costa MF, MonteiroFilho ELA (2011) Using gut contents to assess foraging patterns of juvenile green turtles Chelonia mydas in the Paranaguá Estuary, Brazil. Endang Species Res 13: 131-143
Harms CA, Mallo KM, Ross PM, Segars A (2003) Venous blood gases and lactates of wild loggerhead sea turtles (Caretta caretta) following two capture techniques. J Wildl Dis 39:366-374

*Hoarau L, Ainley L, Jean C, Ciccione S (2014) Ingestion and defecation of marine debris by loggerhead sea turtles, Caretta caretta, from by-catches in the South-West Indian Ocean. Mar Pollut Bull 84:90-96

*Hoopes LA, Landry AM, Stabenau EK (2000) Physiological effects of capturing Kemp's ridley sea turtles, Lepidochelys kempii, in entanglement nets. Can J Zool 78: 1941-1947

*Hopewell J, Dvorak R, Kosior E (2009) Plastic recycling: challenges and opportunities. Philos Trans R Soc B 364: 2115-2126

Jacobsen JK, Massey L, Gulland F (2010) Fatal ingestion of floating net debris by two sperm whales (Physeter macrocephalis). Mar Pollut Bull 60:765-767

Jambeck JR, Geyer R, Wilcox C, Siegler TR and others (2015) Plastic waste inputs from land into the ocean. Science 347:768-771

Jensen MP, Limpus CJ, Whiting SD, Guinea M and others (2013) Defining olive ridley turtle Lepidochelys olivacea management units in Australia and assessing the potential impact of mortality in ghost nets. Endang Species Res 21:241-253

* Jones PD, Hannah DJ, Buckland SJ, Day PJ and others (1996) Persistent synthetic chlorinated hydrocarbons in albatross tissue samples from Midway Atoll. Environ Toxicol Chem 15:1793-1800

Kühn S, van Franeker JA (2012) Plastic ingestion by the northern fulmar (Fulmarus glacialis) in Iceland. Mar Pollut Bull 64:1252-1254

* Kühn S, van Franeker JA (2020) Quantitative overview of marine debris ingested by marine megafauna. Mar Pollut Bull 151:110858

K Lebreton LCM, Greer S, Borrero J (2012) Numerical modeling of floating debris in the world's oceans. Mar Pollut Bull 64:653-661

Kevy AM, Brenner O, Scheinin A, Rather E, Goffman O, Kerem D (2009) Laryngeal snaring by ingested fishing net in a common bottlenose dolphin (Tursiops truncatus) off the Israeli shoreline. J Wildl Dis 45:834-838

* Lithner D, Larsson A, Dave G (2011) Environmental and health hazard ranking and assessment of plastic polymers based on chemical composition. Sci Total Environ 409:3309-3324

พ Lusher AL, Hernandez-Millan G, Berrow S, Rogan E, Connor IO (2018) Incidence of marine debris in cetaceans stranded and bycaught in Ireland: recent findings and a review of historical knowledge. Environ Pollut 232:467-476

Lutz P (1990) Studies on the ingestion of plastic and latex by sea turtles. In: Shomura RS, Godfrey ML (eds) Proc $2^{\text {nd }}$ Int Conf on Marine Debris, 2-7 April 1989, Honolulu, HI. US Department of Commerce, NOAA-TM-NMFS-SWFSC-154

KLynch JM (2018) Quantities of marine debris ingested by sea turtles: global meta-analysis highlights need for standardized data reporting methods and reveals relative risk. Environ Sci Technol 52:12026-12038

Macfayden G, Huntington T, Cappell R (2009) Abandoned, lost or otherwise discarded fishing gear. UNEP Regional Seas Reports and Studies No. 185, FAO Fisheries and Aquaculture Technical Paper No. 523. UNEP/FAO, Rome Mader DR (2006) Reptile medicine and surgery, $2^{\text {nd }}$ edn. Saunders Elsevier, Philadelphia, PA 
Matsuoka T, Nakashima T, Nagasawa N (2005) A review of ghost fishing: scientific approaches to evaluation and solutions. Fish Sci 71:691-702

McCauley SJ, Bjorndal KA (1999) Conservation implications of dietary dilution from debris ingestion: sublethal effects in post-hatchling loggerhead sea turtles. Conserv Biol 13:925-929

Morrison KW, Hipfner JM, Gjerdrum C, Green DJ (2009) Wing length and mass at fledging predict local juvenile survival and age at first return in tufted puffins. Condor 111:433-441

Mrosovsky N, Ryan G, James M (2009) Leatherback turtles: the menace of plastic. Mar Pollut Bull 58:287-289

Neilson JL, Straley JM, Gabriele CM, Hills S (2009) Nonlethal entanglement of humpback whales (Megaptera novaeangliae) in fishing gear in northern Southeast Alaska. J Biogeogr 36:452-464

Nelms SE, Duncan EM, Broderick AC, Galloway TS and others (2015) Plastic and marine turtles: a review and call for research. ICES J Mar Sci 73:165-181

Nelms SE, Coombes C, Foster LC, Galloway TS, Godley BJ, Lindeque PK, Witt MJ (2017) Marine anthropogenic litter on British beaches: a 10-year nationwide assessment using citizen science data. Sci Total Environ 579: 1399-1409

Nelms SE, Galloway TS, Godley BJ, Jarvis DS, Lindeque PK (2018) Investigating microplastic trophic transfer in marine top predators. Environ Pollut 238:999-1007

Nelms SE, Barnett J, Brownlow A, Davison NJ and others (2019) Microplastics in marine mammals stranded around the British coast: Ubiquitous but transitory? Sci Rep 9:1075

* Pfaller JB, Goforth KM, Gill MA, Savoca MS, Lohmann KJ (2020) Odors from marine plastic debris elicit foraging behavior in sea turtles. Curr Biol 30:R213-R214

* Pham CK, Ramirez-Llodra E, Alt CHS, Amaro T and others (2014) Marine litter distribution and density in European seas, from the shelves to deep basins. PLOS ONE 9:e95839

Pierce KE, Harris RJ, Larned LS, Pokras MA (2004) Obstruction and starvation associated with plastic ingestion in a northern gannet Morus bassanus and a greater shearwater Puffinus gravis. Mar Ornithol 32:187-189

* Provencher JF, Gaston AJ, Mallory M (2009) Evidence for increased ingestion of plastics by northern fulmars (Fulmarus glacialis) in the Canadian Arctic. Mar Pollut Bull 58:1092-1095

* Provencher JF, Bond AL, Avery-Gomm S, Borrelle SB and others (2017) Quantifying ingested debris in marine megafauna: a review and recommendations for standardization. Anal Methods 9:1454-1469

* Provencher JF, Liboiron M, Borrelle SB, Bond AL and others (2020) A horizon scan of research priorities to inform policies aimed at reducing the harm of plastic pollution to biota. Sci Total Environ 733:139381

* Pruter AT (1987) Sources, quantities and distribution of persistent plastic in the marine environment. Mar Pollut Bull 18:305-310

Robards MD, Piatt JF, Wohl KD (1995) Increasing frequency of plastic particles ingested by seabirds in the subarctic North Pacific. Mar Pollut Bull 30:151-157

Robbins J, Mattila DK (2004) Estimating humpback whale (Megaptera novaeangliae) entanglement rates on the basis of scar evidence. Report to the Northeast Fisheries Science Center, National Marine Fisheries Service, Woods Hole, MA
Rocha-Santos T, Duarte AC (2015) A critical overview of the analytical approaches to the occurrence, the fate and the behavior of microplastics in the environment. Trends Analyt Chem 65:47-53

Rochman CM, Hoh E, Kurobe T, Teh SJ (2013) Ingested plastic transfers hazardous chemicals to fish and induces hepatic stress. Sci Rep 3:3263

* Rodríguez A, Ramírez F, Carrasco MN, Chiaradia A (2018) Seabird plastic ingestion differs among collection methods: examples from the short-tailed shearwater. Environ Pollut 243:1750-1757

* Ryan PG (2018) Entanglement of birds in plastics and other synthetic materials. Mar Pollut Bull 135:159-164

Ryan PG, Moore CJ, van Franeker JA, Moloney CL (2009) Monitoring the abundance of plastic debris in the marine environment. Philos Trans R Soc B 364:1999-2012

* Santos RG, Andrades R, Boldrini MA, Martins AS (2015) Debris ingestion by juvenile marine turtles: an underestimated problem. Mar Pollut Bull 93:37-43

* Schuyler Q, Hardesty BD, Wilcox C, Townsend K (2012) To eat or not to eat? Debris selectivity by marine turtles. PLOS ONE $7: \mathrm{e} 40884$

Schuyler Q, Hardesty BD, Wilcox C, Townsend K (2014a) Global analysis of anthropogenic debris ingestion by sea turtles. Conserv Biol 28:129-139

Schuyler QA, Wilcox C, Townsend K, Hardesty BD, Marshall NJ (2014b) Mistaken identity? Visual similarities of marine debris to natural prey items of sea turtles. BMC Ecol 14:14

* Schuyler QA, Wilcox C, Townsend KA, Wedemeyer-Strombel KR, Balazs G, van Sebille E, Hardesty BD (2016) Risk analysis reveals global hotspots for marine debris ingestion by sea turtles. Glob Change Biol 22:567-576

Sievert PR, Sileo L (1993) The effects of ingested plastic on growth and survival of albatross chicks. In: Vermeer $\mathrm{K}$, Briggs KT, Morgan KH, Siegal-Causey D (eds) The status, ecology, and conservation of marine birds of the North Pacific. Canadian Wildlife Service Special Publication, Ottawa, p 212-217

* Snoddy JE, Southwood Williard A (2010) Movement and post-release mortality of juvenile sea turtles released from gillnets in the lower Cape Fear River, North Carolina, USA. Endang Species Res 12:235-247

* Snoddy JE, Landon M, Blanvillain G, Southwood A (2009) Blood biochemistry of sea turtles captured in gillnets in the lower Cape Fear River, North Carolina, USA. J Wildl Manag 73:1394-1401

Stabenau E, Vietti K (2003) The physiological effects of multiple forced submergences in loggerhead sea turtles (Caretta caretta). Fish Bull 101:889-899

Talsness CE, Andrade AJM, Kuriyama SN, Taylor JA, vom Saal FS (2009) Components of plastic: experimental studies in animals and relevance for human health. Philos Trans R Soc B 364:2079-2096

พ Tanaka K, Takada H, Yamashita R, Mizukawa K, Fukuwaka M, Watanuki Y (2013) Accumulation of plastic-derived chemicals in tissues of seabirds ingesting marine plastic. Mar Pollut Bull 69:219-222

*Tasker ML, Camphuysen CJ, Cooper J, Garthe S, Montevecchi WA, Blaber SJM (2000) The impacts of fishing on marine birds. ICES J Mar Sci 57:531-547

Terepocki AK, Brush AT, Kleine LU, Shugart GW, Hodum P (2017) Size and dynamics of microplastic in gastrointestinal tracts of northern fulmars (Fulmarus glacialis) and sooty shearwaters (Ardenna grisea). Mar Pollut Bull 116:143-150 
Teuten EL, Saquing JM, Knappe DRU, Barlaz MA and others (2009) Transport and release of chemicals from plastic to the environment and to wildlife. Philos Trans R Soc B 364:2027-2045

Trevail AM, Gabrielsen GW, Kühn S, Van Franeker JA (2015) Elevated levels of ingested plastic in a high arctic seabird, the northern fulmar (Fulmarus glacialis). Polar Biol 38:975-981

Triessnig P, Roetzer A, Stachowitsch M (2012) Beach condition and marine debris: new hurdles for sea turtle hatchling survival. Chelonian Conserv Biol 11:68-77

van der Hoop J, Moore M, Fahlman A, Brocconcelli A and others (2014) Behavioral impacts of disentanglement of a right whale under sedation and the energetic cost of entanglement. Marine Mammal Science 30:282-307

van der Hoop J, Corkeron P, Moore M (2017) Entanglement is a costly life-history stage in large whales. Ecol Evol 7: 92-106

van Franeker JA, Law KL (2015) Seabirds, gyres and global trends in plastic pollution. Environ Pollut 203:89-96

van Franeker JA, Blaize C, Danielsen J, Fairclough K and others (2011) Monitoring plastic ingestion by the northern fulmar Fulmarus glacialis in the North Sea. Environ Pollut 159:2609-2615

van Sebille E, England MH, Froyland G (2012) Origin, dynamics and evolution of ocean garbage patches from observed surface drifters. Environ Res Lett 7:044040

Vegter AC, Barletta M, Beck C, Borrero J and others (2014) Global research priorities to mitigate plastic pollution impacts on marine wildlife. Endang Species Res 25: $225-247$

Verlis KM, Campbell ML, Wilson SP (2014) Marine debris is selected as nesting material by the brown booby (Sula leucogaster) within the Swain Reefs, Great Barrier Reef, Australia. Mar Pollut Bull 87:180-190

vom Saal FS, Akingbemi BT, Belcher SM, Birnbaum LS and others (2007) Chapel Hill bisphenol A expert panel consensus statement: integration of mechanisms, effects in animals and potential to impact human health at current levels of exposure. Reprod Toxicol 24:131-138

Editorial responsibility: Mark Hamann, Townsville, Queensland, Australia
Votier SC, Archibald K, Morgan G, Morgan L (2011) The use of plastic debris as nesting material by a colonial seabird and associated entanglement mortality. Mar Pollut Bull 62:168-172

Wilcox C, Heathcote G, Goldberg J, Gunn R, Peel D, Hardesty BD (2015a) Understanding the sources and effects of abandoned, lost, and discarded fishing gear on marine turtles in Northern Australia. Conserv Biol 29:198-206

Wilcox C, Sebille EV, Hardesty BD (2015b) Threat of plastic pollution to seabirds is global, pervasive, and increasing. Proc Natl Acad Sci USA 112:11899-11904

Wilcox C, Mallos NJ, Leonard GH, Rodriguez A, Hardesty BD (2016) Using expert elicitation to estimate the impacts of plastic pollution on marine wildlife. Mar Policy 65:107-114

*Witherington B (2002) Ecology of neonate loggerhead turtles inhabiting lines of downwelling near a Gulf Stream front. Mar Biol 140:843-853

Witherington B, Hirama S, Hardy R (2012) Young sea turtles of the pelagic Sargassum-dominated drift community: habitat use, population density, and threats. Mar Ecol Prog Ser 463:1-22

WWoodall LC, Sanchez-Vidal A, Canals M, Paterson GLJ and others (2014) The deep sea is a major sink for microplastic debris. R Soc Open Sci 1:140317

WWoodall LC, Gwinnett C, Packer M, Thompson RC, Robinson LF, Paterson GLJ (2015) Using a forensic science approach to minimize environmental contamination and to identify microfibres in marine sediments. Mar Pollut Bull 95:40-46

Yamashita R, Takada H, Fukuwaka M, Watanuki Y (2011) Physical and chemical effects of ingested plastic debris on short-tailed shearwaters, Puffinus tenuirostris, in the North Pacific Ocean. Mar Pollut Bull 62:2845-2849

*Zalko D, Jacques C, Duplan H, Bruel S, Perdu E (2011) Viable skin efficiently absorbs and metabolizes bisphenol A. Chemosphere 82:424-430

Z Zettler ER, Mincer TJ, Amaral-Zettler LA (2013) Life in the 'plastisphere': microbial communities on plastic marine debris. Environ Sci Technol 47:7137-7146

Submitted: April 11, 2020; Accepted: July 21, 2020

Proofs received from author(s): September 19, 2020 